\title{
Model difference in the effect of cilostazol on the development of experimental pulmonary hypertension in rats
}

\author{
Toshikazu Ito ${ }^{1 *}$, Erquan Zhang ${ }^{1,2}$, Ayaka Omori ${ }^{1}$, Jane Kabwe ${ }^{1}$, Masako Kawai ${ }^{1,3}$, Junko Maruyama ${ }^{1,3}$,
} Amphone Okada ${ }^{1}$, Ayumu Yokochi ${ }^{1}$, Hirofumi Sawada ${ }^{1,4}$, Yoshihide Mitani ${ }^{4}$ and Kazuo Maruyama ${ }^{1 *}$

\begin{abstract}
Background: Preventing pulmonary vascular remodeling is a key strategy for pulmonary hypertension (PH). Causes of PH include pulmonary vasoconstriction and inflammation. This study aimed to determine whether cilostazol (CLZ), a phosphodiesterase-3 inhibitor, prevents monocrotaline (MCT)- and chronic hypoxia (CH)-induced PH development in rats.
\end{abstract}

Methods: Fifty-one male Sprague-Dawley rats were fed rat chow with (0.3\% CLZ) or without CLZ for 21 days after a single injection of MCT $(60 \mathrm{mg} / \mathrm{kg})$ or saline. Forty-eight rats were fed rat chow with and without CLZ for 14 days under ambient or hypobaric (air at $380 \mathrm{mmHg}$ ) CH exposure. The mean pulmonary artery pressure (mPAP), the right ventricle weight-to-left ventricle + septum weight ratio (RV/LV + S), percentages of muscularized peripheral pulmonary arteries (\%Muscularization) and medial wall thickness of small muscular arteries (\%MWT) were assessed. Levels of the endothelial nitric oxide synthase (eNOS), phosphorylated eNOS (peNOS), AKT, pAKT and IkB proteins in lung tissue were measured using Western blotting. Monocyte chemotactic protein (MCP)-1 mRNA in lung tissue was also assessed.

Results: $\operatorname{mPAP}[35.1 \pm 1.7 \mathrm{mmHg}(\mathrm{MCT})(\mathrm{n}=9)$ vs. $16.6 \pm 0.7$ (control) $(\mathrm{n}=9)(P<0.05) ; 29.1 \pm 1.5 \mathrm{mmHg}(\mathrm{CH})$ $(n=10)$ vs. $17.5 \pm 0.5$ (control) $(n=10)(P<0.05)], R V / L V+S[0.40 \pm 0.01(M C T)(n=18)$ vs. $0.24 \pm 0.01$ (control) $(n=10)$ $(P<0.05) ; 0.41 \pm 0.03(\mathrm{CH})(\mathrm{n}=13)$ vs. $0.27 \pm 0.06$ (control) $(\mathrm{n}=10)(P<0.05)]$, and \%Muscularization and \%MWT were increased by MCT injection and CH exposure. CLZ significantly attenuated these changes in the MCT model [mPAP $25.1 \pm 1.1 \mathrm{mmHg}(n=11)(P<0.05), \mathrm{RV} / \mathrm{LV}+\mathrm{S} 0.30 \pm 0.01(n=14)(P<0.05)]$. In contrast, these CLZ effects were not observed in the $\mathrm{CH}$ model. Lung eNOS protein expression was unchanged in the MCT model and increased in the $\mathrm{CH}$ model. Lung protein expression of AKT, phosphorylated AKT, and IKB was downregulated by MCT, which was attenuated by CLZ; the $\mathrm{CH}$ model did not change these proteins. Lung MCP-1 mRNA levels were increased in MCT rats but not $\mathrm{CH}$ rats.

Conclusions: We found model differences in the effect of CLZ on PH development. CLZ might exert a preventive effect on $\mathrm{PH}$ development in an inflammatory $\mathrm{PH}$ model but not in a vascular structural change model of $\mathrm{PH}$ preceded by vasoconstriction. Thus, the preventive effect of CLZ on PH development might depend on the PH etiology.

\footnotetext{
*Correspondence: i-toshikazu@med.mie-u.ac.jp; k-maru@med.mie-u.ac.jp

${ }^{1}$ Department of Anesthesiology and Critical Care Medicine, Mie

University Graduate School of Medicine, 2-174 Edobashi, Tsu, Mie

514-8507, Japan

Full list of author information is available at the end of the article
}

(c) The Author(s) 2021. Open Access This article is licensed under a Creative Commons Attribution 4.0 International License, which permits use, sharing, adaptation, distribution and reproduction in any medium or format, as long as you give appropriate credit to the original author(s) and the source, provide a link to the Creative Commons licence, and indicate if changes were made. The images or other third party material in this article are included in the article's Creative Commons licence, unless indicated otherwise in a credit line to the material. If material is not included in the article's Creative Commons licence and your intended use is not permitted by statutory regulation or exceeds the permitted use, you will need to obtain permission directly from the copyright holder. To view a copy of this licence, visit http://creativecommons.org/licenses/by/4.0/. The Creative Commons Public Domain Dedication waiver (http://creativeco mmons.org/publicdomain/zero/1.0/) applies to the data made available in this article, unless otherwise stated in a credit line to the data. 
Keywords: Monocrotaline, Chronic hypoxia, Cilostazol, Pulmonary hypertension, Nitric oxide

\section{Background}

Pulmonary hypertension $(\mathrm{PH})$ is characterized by an increase in pulmonary artery pressure (PAP), right ventricular hypertrophy (RVH), and functional and/ or structural vascular changes $[1,2]$. Possible causes of $\mathrm{PH}$ include pulmonary vasoconstriction, diffuse microthromboembolism, and pulmonary vascular remodeling [1-3]. In all conditions causing $\mathrm{PH}$ in humans [3-5] and experimental models [6-20], vascular changes include new muscularization of normally nonmuscular peripheral pulmonary arteries and medial hypertrophy of muscular arteries. PH may be encountered in the intensive care unit in patients with acute respiratory distress syndrome (ARDS) [21-23], congenital heart disease with left-to-right shunt [3, 24, 25], mitral valve disease [26], and interstitial pulmonary fibrosis [27], as well as after cardiothoracic surgery [28, 29]. Nitric oxide (NO) is a vasodilator and suppressor of smooth muscle cell proliferation [1, 2], and the bioavailability of $\mathrm{NO}$ is reduced in patients with $\mathrm{PH}$ and in experimental $\mathrm{PH}$ models [30-32]. We and other researchers have shown that modulators that increase $\mathrm{NO}$ production ameliorate the development of $\mathrm{PH}$ and vascular remodeling $[6,7,33]$.

Cilostazol (CLZ) is a selective phosphodiesterase-3 inhibitor that increases intracellular cyclic AMP levels, which inhibits platelet aggregation and induces peripheral vasodilation. The antiplatelet agent CLZ is indicated for intermittent claudication in patients with peripheral arterial disease [34], thrombotic complications of coronary angioplasty [35] and secondary stroke prevention [36]. Through cAMP-dependent and cAMP-independent mechanisms, CLZ also induces the phosphorylation of endothelial nitric oxide synthase (eNOS), which increases NO production in the aortas of diabetic rats [37], human aortic endothelial cells [38], and rat cultured smooth muscle cells [39]. CLZ also exerts anti-inflammatory effects [40-42]. By activating the NO synthase-NO pathway or preventing inflammatory responses, CLZ might prevent the development of $\mathrm{PH}$, as suggested in an earlier study [43] in which $\mathrm{PH}$ was not fatal. Since the pathogenesis and severity of $\mathrm{PH}$ are heterogeneous $[1-3,44]$, we determined the effect of CLZ on the development of two established experimental models of PH: rat models of MCT-induced PH $[6,8,12-15,17,18,33,43,45-50]$ and chronic hypoxia $(\mathrm{CH})$-induced $\mathrm{PH}[6,7,9-11,19,20,31,32,51]$. The rats with MCT-induced $\mathrm{PH}$ used in this study were a model of experimental fatal $\mathrm{PH}$.

\section{Methods}

The Animal Experiment Committee of Mie University School of Medicine approved the study protocol (Nos. 20-34 and 20-35). Rats were fed rat chow containing $0.3 \%$ CLZ [52] or control chow without CLZ. Rat chow with and without CLZ was a gift from Otsuka Pharmaceutical Co., Ltd (Tokushima, Japan). Sprague-Dawley rats were obtained from Japan SLC, Inc. In total 159 rats were used. For euthanasia rats were administered $50 \mathrm{mg} /$ $\mathrm{kg}$ pentobarbital sodium (Somnopentil ${ }^{\circledR}$, Kyorituseiyaku Corporation, Japan) via intraperitoneal injection. After obtaining no consciousness with respiratory depression and no response to the stimulation, which took about 5-10 min and showed deep anesthesia, rats were put under mechanical ventilation through tracheostomy. Then the abdomen was incised and the rats were exsanguinated by aortic incision and heart and lung samples were removed.

\section{Animal groups \\ MCT21 model}

Seven-week-old male Sprague-Dawley rats (SLC, Japan) weighing 185-245 g were used. Rats were fed rat chow with or without CLZ one day before the administration of a single injection of MCT ( $60 \mathrm{mg} / \mathrm{kg}$, Sigma) or saline and continued to be fed the same rat chow for another 21 days (Fig. 1A). Each animal was randomly assigned to one of four groups: (1) a single injection of saline and rat chow without CLZ (Sal21/CLZ-) $(\mathrm{n}=10),(2)$ a single injection of saline and rat chow with CLZ (Sal21/CLZ+) $(\mathrm{n}=9)$, (3) a single injection of MCT and rat chow without CLZ (MCT21/CLZ-) $(\mathrm{n}=18)$, and 4) a single injection of MCT and rat chow with CLZ (MCT21/CLZ+) $(\mathrm{n}=14)$. MCT $(60 \mathrm{mg} / \mathrm{kg})[12-15,45,48,50]$ or the same volume of $0.9 \% \mathrm{NaCl}$ was subcutaneously injected into the hind flank.

\section{$\mathrm{CH}$ model}

Seven-week-old male Sprague-Dawley rats (SLC, Japan) weighing 187-235 g were used. Rats were fed rat chow with or without CLZ beginning one day before the start of hypobaric $\mathrm{CH}$ exposure (air at $380 \mathrm{mmHg}$ ) and continued to be fed the same rat chow until the final day of ambient air or $\mathrm{CH}$ exposure (Fig. 2A). Each animal was randomly assigned to one of four groups: (1) rats exposed to ambient air without CLZ (Air/CLZ-) $(\mathrm{n}=10)$, (2) rats exposed to ambient air with CLZ, (Air/CLZ+) $(n=10)$, (3) rats exposed to $\mathrm{CH}$ without $\mathrm{CLZ}(\mathrm{CH} / \mathrm{CLZ}-)(\mathrm{n}=14)$ and (4) rats exposed to $\mathrm{CH}$ with $\mathrm{CLZ}(\mathrm{CH} / \mathrm{CLZ}+)$ 

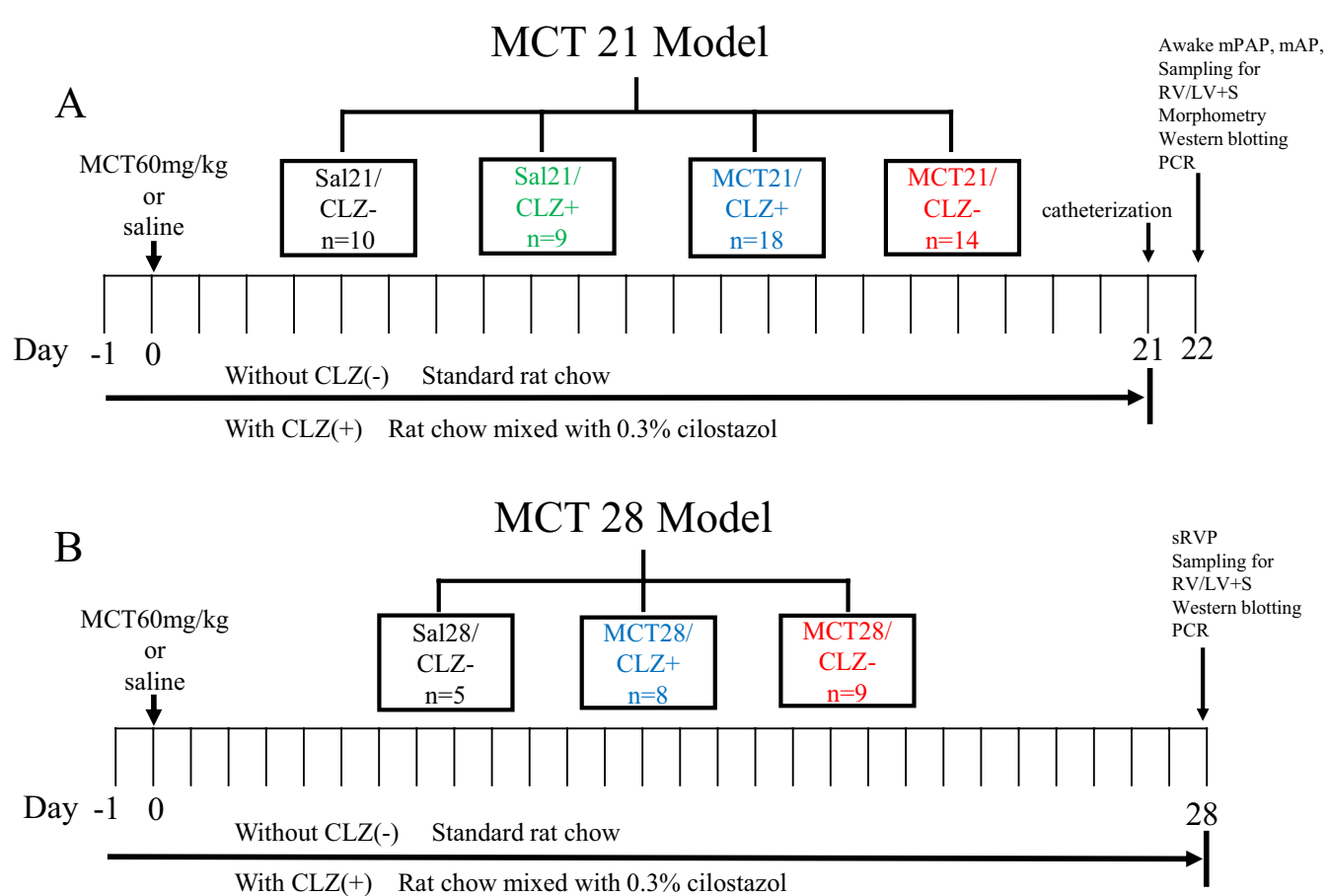

Fig. 1 Experimental protocol used to establish the MCT21 and MCT28 models. A, MCT21 model: pulmonary and carotid arteries were catheterized 21 days after the MCT or saline injection; awake mean pulmonary artery pressure (mPAP) and mean artery pressure (mAP) were measured at day 22 when rats were fully awake; lung and heart samples were obtained for measurements of the right ventricle (RV) weight-to-left ventricle + septum $(L V+S)$ weight ratio $(R V / L V+S)$, morphometry of pulmonary arteries, Western blotting and PCR after the pressure measurements. B, MCT28 model: measurement of systolic right ventricular pressure (sRVP) under anesthesia and sampling for RV/LV + S, Western blotting and PCR were performed 28 days after the injection of MCT or saline. Sal/CLZ-, rats injected with saline and fed rat chow without cilostazol (CLZ); Sal/CLZ+, rats injected with saline and fed rat chow with CLZ; MCT/CLZ-, rats injected with MCT and fed rat chow without CLZ; MCT/CLZ +, rats injected with MCT and fed rat chow with CLZ. MCT, monocrotaline; Sal, saline; $n=$, number of rats used. We were not always successful in obtaining all these datasets or samples for each assigned rat because of technical reasons, especially when recording mPAP, and thus the number of rats used (n) was not always the same as the numbers listed in Figs. 5, 6, and 9

$(\mathrm{n}=14)$. Rats were exposed to hypoxia for 14 days and returned to ambient air after catheterization [6, 9-11].

\section{MCT28 model}

We performed a limited study with 3 groups (Sal28/ CLZ-, MCT28/CLZ-, and MCT28/CLZ+) to determine whether the observations recorded in rats for 21 days would persist for 28 days. In the MCT28 model, each animal injected with saline or MCT $(60 \mathrm{mg} / \mathrm{kg})$ was randomly assigned to one of three groups (Fig. 1B): Sal28/CLZ- $(\mathrm{n}=5)$, MCT28/CLZ- $(\mathrm{n}=8)$, and MCT28/ $\mathrm{CLZ}+(\mathrm{n}=9)$. Rats were fed for 28 days after the injection of MCT as in the MCT21 model. The MCT2 8 model rats were used to evaluate systolic right ventricular pressure (sRVP) under $45 \mathrm{mg} / \mathrm{kg}$ pentobarbital anesthesia and $\mathrm{RVH}$ and to obtain lung samples for protein and mRNA assays (Fig. 1B). The MCT21 and $\mathrm{CH}$ model rats were used to evaluate awake mean PAP (mPAP), right ventricle weight-to-left ventricle + septum weight ratio $(\mathrm{RV} / \mathrm{LV}+\mathrm{S})$, and pulmonary vascular structural changes and to obtain lung samples for protein and mRNA assays (Figs. 1A, 2A).

\section{mPAP and mean artery pressure (mAP) in MCT21 and $\mathrm{CH}$, and sRVP in MCT28}

At the end of 21 days after the MCT injection and 14 days of $\mathrm{CH}$ exposure, a pulmonary artery catheter (silastic tubing, $0.31 \mathrm{~mm}$ ID and $0.64 \mathrm{~mm}$ OD) was inserted into rats through the right external jugular vein into the pulmonary artery employing a closed-chest technique under $45 \mathrm{mg} / \mathrm{kg}$ pentobarbital anesthesia with no tail movement upon stimulation $[10,11,13]$ (Figs. 1A, 2A). The left internal carotid artery was also cannulated. Twentyfour hours after the catheterization, the mPAP and mAP were recorded in fully conscious rats with a physiological transducer and an amplifier system (AP 620G, Nihon Kohden, Japan) once the rats were calm (Figs. 1A, 2A).

In the MCT28 model, at the end of 28 days after MCT injection, sRVP was measured in rats under $45 \mathrm{mg} /$ $\mathrm{kg}$ pentobarbital anesthesia using the closed-chest 


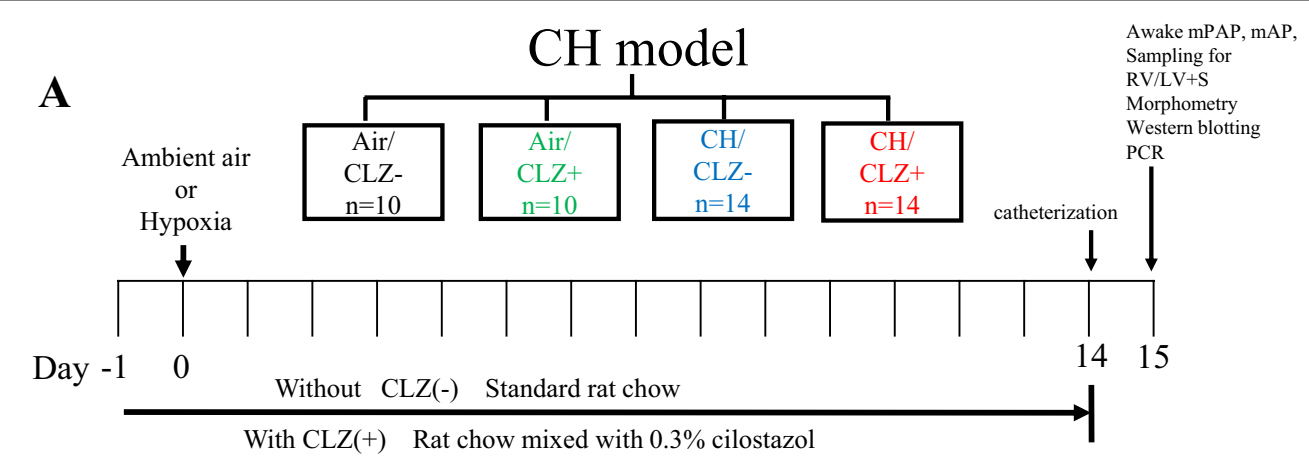

B
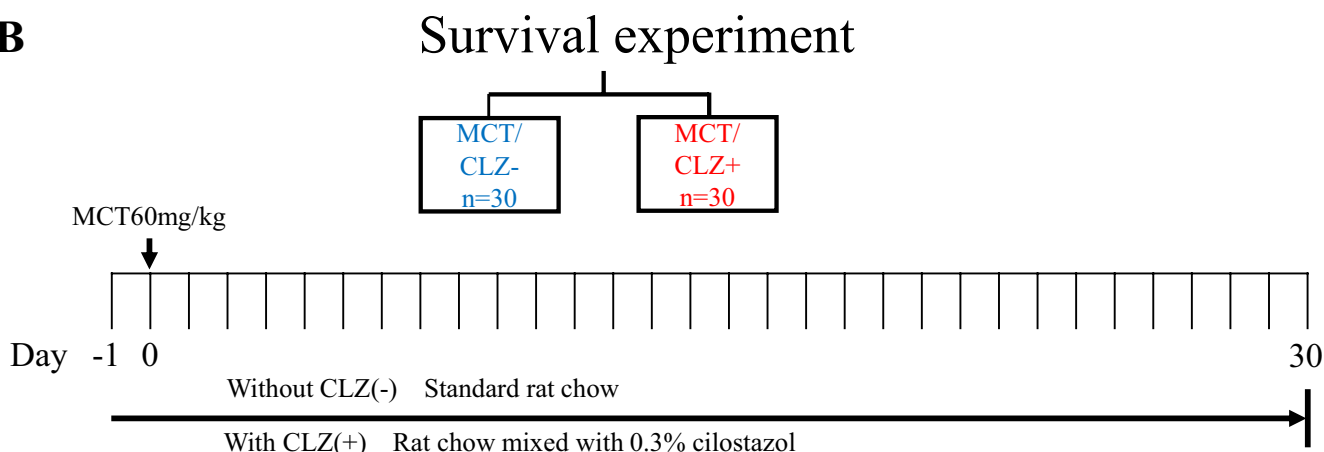

Fig. 2 Experimental protocol used to establish the $\mathrm{CH}$ model and survival study. A, $\mathrm{CH}$ model: Pulmonary and carotid arteries were catheterized on the final day of chronic hypoxia $(\mathrm{CH})$ exposure; awake mean pulmonary artery pressure (mPAP) and mean artery pressure (mAP) were measured on day 15 with rats fully awake; lung and heart samples were obtained for measurements of the right ventricle weight-to-left ventricle + septum weight ratio (RV/LV+S), morphometry of pulmonary arteries, Western blotting and PCR after the pressure measurements. Air/CLZ-, rats exposed to ambient air and fed rat chow without CLZ; Air/CLZ +, rats exposed to ambient air and fed rat chow with CLZ; CH/CLZ-, rats exposed to chronic hypoxia and fed rat chow without $\mathrm{CLZ} ; \mathrm{CH} / \mathrm{CLZ}+$, rats exposed to chronic hypoxia and fed rat chow with $\mathrm{CLZ}$. (n) = number of rats used. The number of rats used (n) was not always the same as the numbers listed in Figs. 5, 6 and 10. See the legend of Fig. 1. B, Survival experiment. MCT/ CLZ-, rats injected with MCT and fed rat chow without CLZ. MCT/CLZ +, rats injected with MCT and fed rat chow with CLZ. MCT, monocrotaline; $(n)=$ number of rats used

technique, and then lung samples for protein and mRNA assays were obtained (Fig. 1B).

\section{Preparation of lung tissue for morphometric analysis and lung tissue sampling for protein and mRNA assays} After the measurement of awake mPAP in the MCT21 and $\mathrm{CH}$ models, the rats were anesthetized with $50 \mathrm{mg} /$ $\mathrm{kg}$ pentobarbital again and mechanically ventilated through tracheostomy. The abdomen was then incised, and the abdominal aorta was incised to cause blood loss and euthanasia. A midline sternotomy was performed to expose the heart and lung. The hilum of the right lung was ligated, and the right lung was excised and placed in liquid nitrogen for real-time polymerase chain reaction (PCR) and Western blotting of whole lung tissue. Blood samples were collected for the hematocrit measurement. Sections of the left lung were prepared for a morphometric analysis of the vasculature using the barium injection method [6,9-14] to identify peripheral pulmonary arteries. Briefly, the left pulmonary artery was injected with a hot radiopaque barium-gelatin mixture at $100 \mathrm{~cm}$ $\mathrm{H}_{2} \mathrm{O}$ pressure [6, 9-14]. After injection, the lung was distended and perfused through the tracheal tube with $10 \%$ formalin at $36 \mathrm{~cm} \mathrm{H}_{2} \mathrm{O}$ pressure for $72 \mathrm{~h}$. Sections were stained for elastin using the Van Gieson method. The right ventricle (RV) of the heart was dissected from the left ventricle plus septum $(\mathrm{LV}+\mathrm{S})$ and weighed separately. The heart weight ratio $(\mathrm{RV} / \mathrm{LV}+\mathrm{S})$ was calculated to assess RVH. We also evaluated fibrosis in the right ventricle by performing Masson's trichrome staining for collagen in 3 randomly selected heart tissue samples from each group (Air/CLZ-(control), MCT21/CLZ-, MCT21/ $\mathrm{CLZ}+, \mathrm{CH} / \mathrm{CLZ}-$, and $\mathrm{CH} / \mathrm{CLZ}+)$. Lung sampling from the MCT28 group is described above.

\section{Morphometric analysis of pulmonary arteries}

Sections were analyzed under a light microscope by an investigator without previous knowledge of the treatment 
groups. All barium-filled arteries in each tissue section were examined at $\times 400$ magnification, for an average of 220 arteries per section (110-340 arteries per section). Each artery was identified as being one of two structural types to determine the presence of muscularity: muscularized (with a complete medial coat, incomplete medial coat, or only a crescent of muscle being present) and nonmuscular (no muscle apparent) [6, 9-14]. The percentages of muscularized arteries (\%Muscularization) in peripheral pulmonary arteries with an external diameter between 15 and $50 \mu \mathrm{m}$ and those between 51 and $100 \mu \mathrm{m}$ were calculated. For muscular arteries between 101 and $200 \mu \mathrm{m}$ in diameter (an average of 18 arteries (5-20 arteries) were observed in each section), the wall thickness of the media (distance between external and internal elastic laminae) was measured along the shortest curvature, and the percent medial wall thickness (\%MWT), the ratio of the wall thickness of the media to the external diameter in muscular arteries, was calculated [6, 9-14].

\section{Western blotting for eNOS, peNOS, AKT, pAKT, ІкB, and HMGB-1}

For Western blotting, lung samples were randomly selected from the MCT21, MCT28, and $\mathrm{CH}$ models, where all pooled lung samples were unable to be used because of the number of gel lanes. Samples were homogenized, and the supernatant was standardized to a concentration of $3.0 \mathrm{mg} / \mathrm{ml}$. Thirty micrograms of total protein from each sample were subjected to SDS-PAGE on $10 \%$ polyacrylamide gels (Nacalai, Japan) and blotted onto a PVDF membrane (Amersham Hybond-P, GE Healthcare). Blots were blocked for $1 \mathrm{~h}$ with $5 \%$ skim milk diluted in $0.1 \%$ TBST (Tris-buffered saline plus Tween) followed by an overnight incubation at $4{ }^{\circ} \mathrm{C}$ with a primary antibody diluted in Can Get Signal Immunoreaction Enhancer Solution 1 (Toyobo Co. Ltd., Japan). Six different primary antibodies against the following proteins were used: endothelial nitric oxide synthase (eNOS) (BD Transduction Laboratories; G10296, lot 21527, 1:4000 dilution), phosphorylated eNOS (peNOS) (Cell Signaling; phospho-eNOS, ser-1177 \#9751, 1:2000 dilution), serine-threonine protein kinase (AKT) (Cell Signaling; \#4814S, 1:2000 dilution), phosphorylated AKT (pAKT) (Cell Signaling; \#460P, 1:2000 dilution), IкB- $\alpha$ (Cell Signaling; \#4814S, 1:2000 dilution), high-mobility group box-1 (HMGB-1) (Cell Signaling; \#3935S, 1:2000 dilution), and $\beta$-actin (Sigma; A5441, 1:200,000 dilution). Next, the blots were incubated with the secondary antibody (Amersham NA 931, 1:20,000 dilution) diluted in Can Get Signal Immunoreaction Enhancer Solution 2 (Toyobo Co. Ltd., Japan) for $1 \mathrm{~h}$ at room temperature and in Immobilon Western Chemiluminescent HRP Substrate (Millipore Corporation, USA) for $5 \mathrm{~min}$.
Luminescent signals were captured digitally, and densitometry was performed using Multi Gauge Ver. 3.0 (Fujifilm, Science Laboratory 2005, Japan). Each target protein was normalized to $\beta$-actin, and the relative fold change compared to the control group (100\%) was calculated.

\section{CDNA preparation and PCR}

Levels of the eNOS, AKT, and monocyte chemotactic protein-1 (MCP-1) mRNAs in whole lung tissue were determined using real-time PCR. After the extraction of total RNA from whole lung tissue using TRIzol reagent (Invitrogen, USA), cDNA synthesis was performed with ReverTra Ace (Toyobo Co., Ltd., Biochemical Operations Department, Osaka, Japan). The cDNA templates (15 ng of total RNA) were amplified with a StepOne Plus Real Time PCR System (Applied Biosystems). The sequences of the primer pairs are listed in Table 1. Relative quantification was performed with the comparative $\Delta \Delta \mathrm{Ct}$ method by normalization to the $\beta$-actin mRNA.

\section{Survival experiment}

Sixty rats (7-week-old male Sprague-Dawley rats (SLC, Japan)) were used. Each rat was randomly assigned to one of two groups: 30 rats (weighing 213-234 g) fed rat chow without CLZ and 30 rats (195-233 g) fed rat chow with CLZ (Fig. 2B). The rat chow with CLZ (including $0.3 \% \mathrm{CLZ}$ ) was the same as that provided to establish the MCT21, MCT28, and CH models. One day after the assignment of the feeding group, all rats were subcutaneously injected with MCT $(60 \mathrm{mg} / \mathrm{kg})$. Food and water were provided ad libitum. The number of living rats was counted daily, and the Kaplan-Meier survival curve was constructed for up to 30 days after the injection of MCT.

\section{Data analysis}

Values are presented as the means $\pm S E$. When more than two means were compared, one-way analysis of variance was used. When significant variance was found, Fisher's

Table1 Primer list

\begin{tabular}{ll}
\hline Gene name & Primer $\left(\mathbf{5}^{\prime}-\mathbf{3}^{\prime}\right)$ sequence \\
\hline eNOS & F: ATGGATGAGCCAACTCAAGG \\
& R: GGCTGCAGTCCTTTGATCTC \\
AKT & F: GGTCGTGGGTCTGGAATG \\
& R: AGAAGGAGGTCATCGTTGC \\
MCP-1 & R:AGAACTTGACCCATAAATCTGAAG \\
& F: GACGGTCAGATTCCAAATCAC \\
ACTB & R:TAG TTTCATGGATGCACACATCG \\
\end{tabular}

eNOS, Endothelial nitric oxide synthase; AKT, Serine-threonine kinase; MCP-1, Monocyte chemotactic protein-1; ACTB, $\beta$-actin 
protected least significant difference test was employed to establish which groups were different. Survival was evaluated using the Breslow-Gehan-Wilcoxon test in StatView5.0 software. Differences were considered significant at $P<0.05$.

\section{Results}

\section{Body weight}

\section{MCT21 model}

All rats gained body weight steadily. MCT rats had significantly lower body weights than saline control rats from day 4 to the last day of the experiment, probably due to the lower amount of food intake. A previous study, where daily food intake was measured, reported less food intake in MCT rats than in control rats (12), which showed that MCT rats might have less of an appetite, and our present results are at least partially consistent with this observation. CLZ had no effects on body weight gain in either the MCT or saline control rats (Fig. 3A).

\section{$\mathrm{CH}$ model}

$\mathrm{CH}$-exposed rats lost weight during the first several days of hypoxia exposure but regained weight afterward. The air-exposed rats gained weight steadily. After the start of hypoxia exposure, $\mathrm{CH}$-exposed rats showed significantly

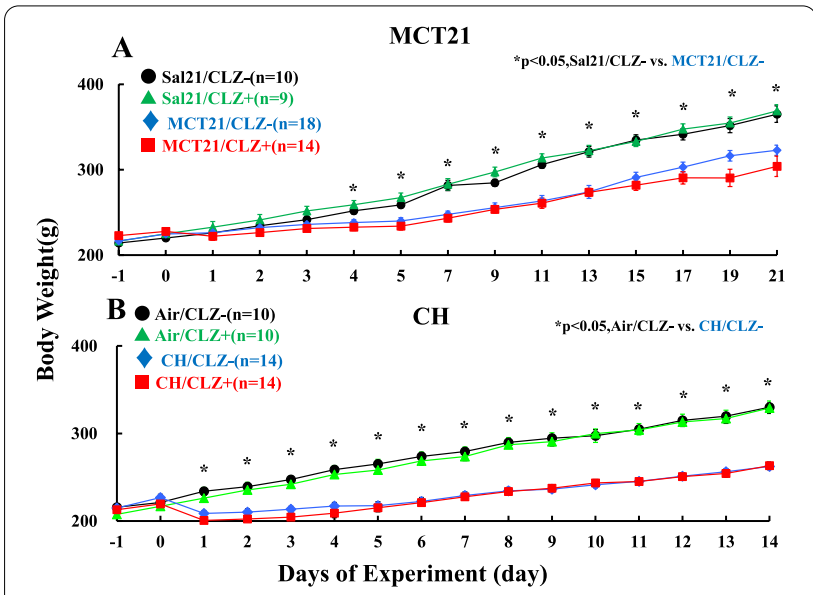

Fig. 3 Body weight. A Rats injected with monocrotaline (MCT). Sal21/CLZ-, rats injected with saline and fed rat chow without cilostazol (CLZ); Sal21/CLZ +, rats injected with saline and fed rat chow with CLZ; MCT21/CLZ-, rats injected with MCT and fed rat chow without CLZ; MCT21/CLZ +, rats injected with MCT and fed rat chow with $C L Z$. $(n)=$ number of rats, means $\pm S E$. $* P<0.05$, comparison of the Sal/CLZ- group and the MCT/CLZ- group. $\mathbf{B}$ Rats exposed to chronic hypoxia (CH). Air/CLZ-, rats exposed to ambient air and fed rat chow without $\mathrm{CLZ}$; Air/CLZ+, rats exposed to ambient air and fed rat chow with $\mathrm{CLZ} ; \mathrm{CH} / \mathrm{CLZ}-$, rats exposed to chronic hypoxia and fed rat chow without $\mathrm{CLZ} ; \mathrm{CH} / \mathrm{CLZ}+$, rats exposed to chronic hypoxia and fed rat chow with $C L Z$. $(n)=$ number of rats, means $\pm S E$. $\boldsymbol{*} P<0.05$, comparison of the air/CLZ- group and the CH/CLZ- group lower body weights than air-exposed rats. CLZ treatment had no effect on the body weight of either air- or $\mathrm{CH}$ exposed rats (Fig. 3B).

\section{Dosage of CLZ MCT model}

Approximate dosages (mg) of CLZ were calculated using the equation: food intake $(\mathrm{g}) \times 0.003 \times 1000$, which is the average dosage per kg per day throughout the experimental course. The dosage of CLZ was $\sim 230 \mathrm{mg} / \mathrm{kg} /$ day in the Sal/CLZ+ group and $200 \mathrm{mg} / \mathrm{kg} /$ day in the MCT/ CLZ+ group (Fig. 4A). Although the dosage decreased to $64 \mathrm{mg} / \mathrm{kg} /$ day on the day of MCT injection, the dosage was similar in the Sal/CLZ+ and MCT/CLZ+groups beginning on day 4 and thereafter throughout the experiment.

\section{$\mathrm{CH}$ model}

The dosage of CLZ was $\sim 250 \mathrm{mg} / \mathrm{kg} /$ day in the Air/CLZ + group and $\sim 220 \mathrm{mg} / \mathrm{kg} /$ day in the $\mathrm{CH} /$ CLZ+ group (Fig. 4B). Although the dosage decreased to $11 \mathrm{mg} / \mathrm{kg} /$ day on the first day of hypoxia exposure,

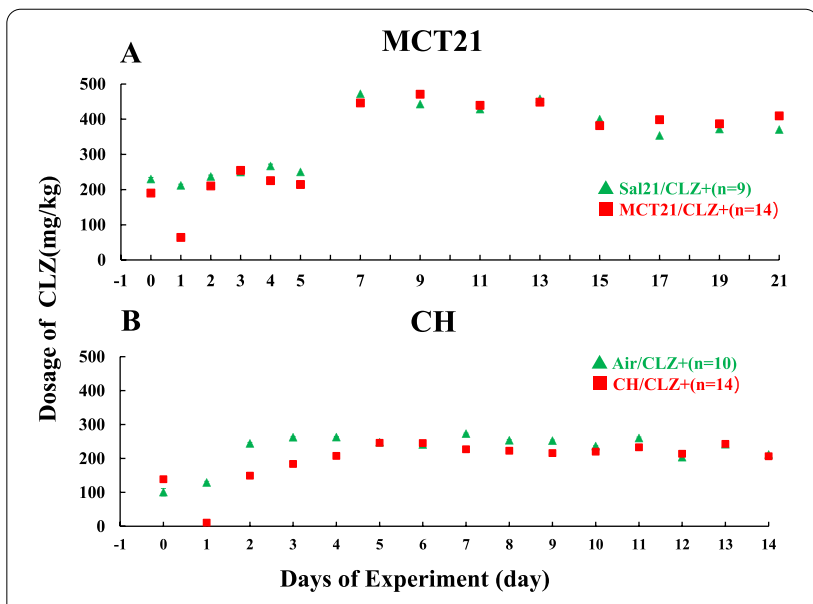

Fig. 4 Dosage of CLZ calculated based on food intake. A, Rats injected with monocrotaline (MCT). Each plot is the average dosage per kg per day (from day 0 to day 5) or per 2 days (from day 7 to day 21) for a rat. For example, the plot of day 0 is the dosage a rat had consumed for $24 \mathrm{~h}$ from day -1 to day 0 , and the plot of day 21 is the dosage a rat had consumed for $48 \mathrm{~h}$ from day 19 to day 21. Sal21/ $\mathrm{CLZ}+$, rats injected with saline and fed rat chow with CLZ; MCT21/ $\mathrm{CLZ}+$, rats injected with MCT and fed rat chow with CLZ. B, Rats exposed to chronic hypoxia $(\mathrm{CH})$. Each plot is the average dosage per $\mathrm{kg}$ per day. For example, the plot of day 0 is the dosage a rat had consumed for $24 \mathrm{~h}$ from day -1 to day 0 , and the plot of day 14 is the dosage a rat had consumed for $24 \mathrm{~h}$ from day 13 to day 14 . Air/CLZ+, rats exposed to ambient air and fed rat chow with $\mathrm{CLZ} ; \mathrm{CH} / \mathrm{CLZ}+$, rats exposed to chronic hypoxia and fed rat chow with $C L Z$ 
the dosage was similar in the Air/CLZ+ and $\mathrm{CH} /$ $\mathrm{CLZ}+$ groups from day 4 throughout the experiment.

\section{$\mathrm{mPAP}, \mathrm{mPAP} / \mathrm{mAP}, \mathrm{RV} / \mathrm{LV}+\mathrm{S}, \mathrm{mAP}$ and $\mathrm{sRVP}$ MCT21 model}

When comparing the effects of MCT administration between the Sal21/CLZ- and MCT21/CLZ- groups, mPAP $[16.56 \pm 0.73(\mathrm{n}=9)$ vs. $35.33 \pm 1.67(\mathrm{n}=9) \mathrm{mmHg}$ $(P<0.05)$ (Fig. $5 \mathrm{~A})], \mathrm{mPAP} / \mathrm{mAP}[0.16 \pm 0.01(\mathrm{n}=8)$ vs. $0.38 \pm 0.01(\mathrm{n}=8)(P<0.05) \quad$ (Fig. 5D)], and $\mathrm{RV} / \mathrm{LV}+\mathrm{S}$ $[0.24 \pm 0.01 \quad(\mathrm{n}=10) \quad$ vs. $0.40 \pm 0.01 \quad(\mathrm{n}=18) \quad(P<0.05)$ (Fig. 5F)] were all significantly higher in the MCT21/ CLZ- group, suggesting that MCT caused $\mathrm{PH}$ and $\mathrm{RVH}$. In the comparison of the effects of CLZ treatment between the MCT21/CLZ+ and MCT21/CLZ- groups, mPAP $[25.09 \pm 1.06 \mathrm{mmHg}(\mathrm{n}=11)(P<0.05)], \mathrm{mPAP} /$ $\mathrm{mAP}[0.25 \pm 0.01(\mathrm{n}=11)]$, and $\mathrm{RV} / \mathrm{LV}+\mathrm{S}[0.30 \pm 0.01$ $(\mathrm{n}=14)]$ in MCT21/CLZ + were significantly lower than the values of the MCT21/CLZ- group (Fig. 5A, $\mathrm{D}, \mathrm{F})$, suggesting that CLZ treatment ameliorated the development of $\mathrm{PH}$ and $\mathrm{RVH}$. No significant differences in mAP were observed among the 4 groups (mAP: Sal21/ CLZ- 104.44 $\pm 3.59(\mathrm{n}=9)$, Sal21/CLZ $+108.89 \pm 10.03$ $(\mathrm{n}=9)$, MCT21/CLZ- $93.56 \pm 1.80 \quad(\mathrm{n}=16), \mathrm{MCT} 21 /$ CLZ + 103.71 $\pm 6.92(\mathrm{n}=14) \mathrm{mmHg})($ Fig. 6A).

The staining of collagen fibers in the right ventricle was obtained in control rat (Fig. 7A). The staining of collagen fibers in the right ventricle was increased in MCT 21 rat, but CLZ treatment did not seem to decrease this increased staining (Fig. 7B, C).

\section{MCT28 model}

$\mathrm{PH}$ in MCT rats is progressive, and PAP becomes extremely high. For MCT28 rats, the effect of CLZ was evaluated by measuring systolic right ventricular pressure (sRVP). We measured systolic right ventricular pressure (sRVP) in MCT28 rats under anesthesia instead of awake mPAP because obtaining mPAP in the MCT28 group is technically difficult. Anesthesia might affect sRVP. When comparing the effects of MCT administration between

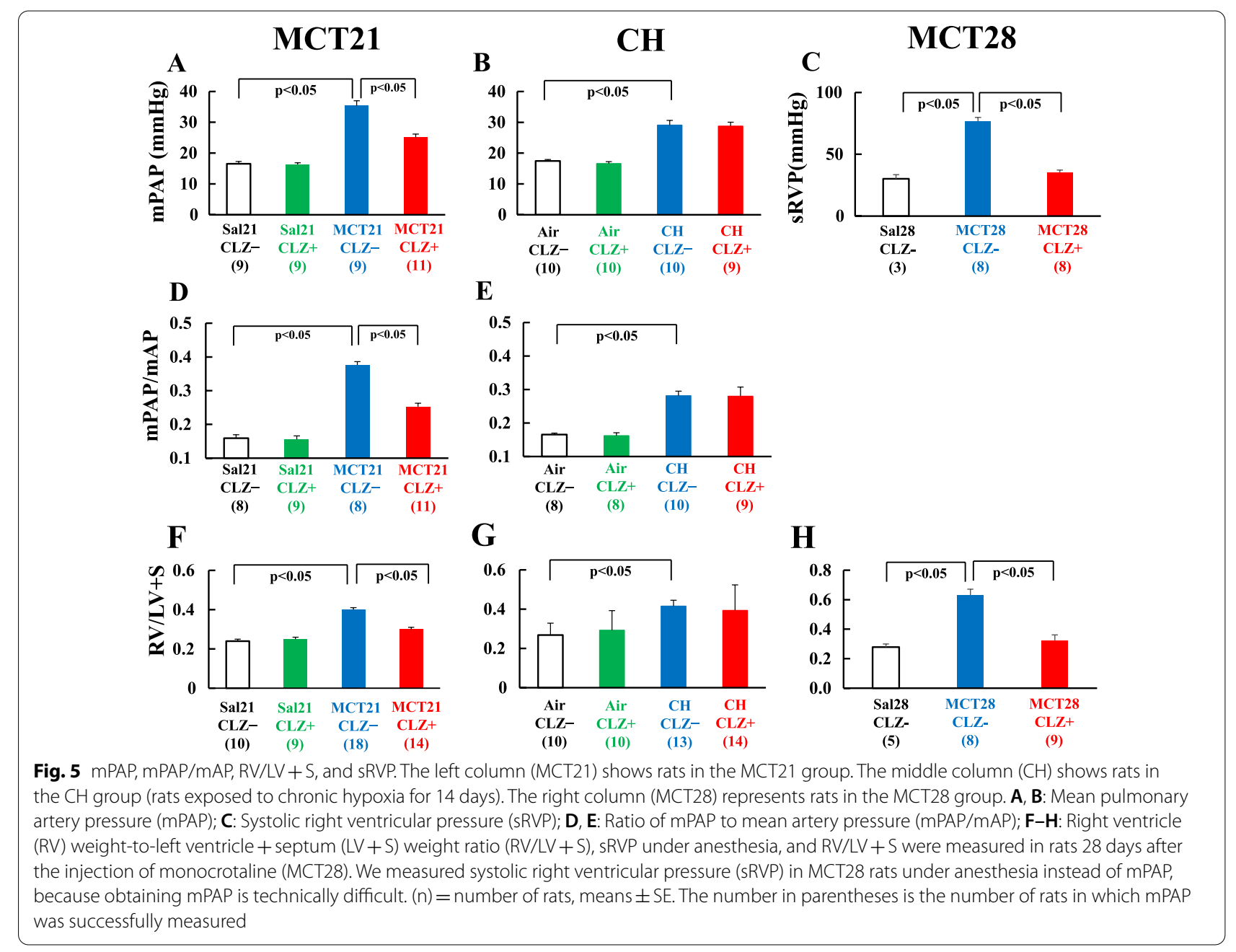



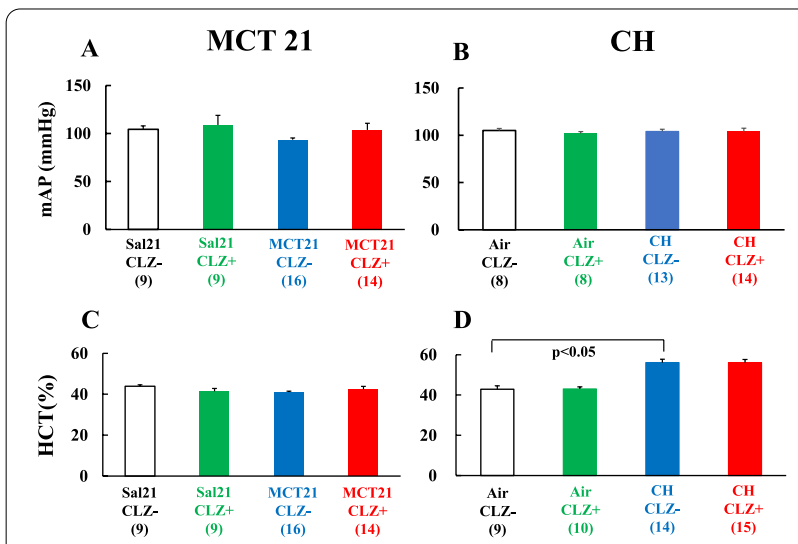

Fig. 6 Mean artery pressure (mAP), and hematocrit (HCT). The left column (MCT21) represents in rats in the MCT21 group. The right column $(\mathrm{CH})$ shows rats in the $\mathrm{CH}$ group (rats exposed to chronic hypoxia for 14 days). A: Mean artery pressure in the MCT21 group; B: Mean artery pressure in the $\mathrm{CH}$ group; $\mathbf{C}$ : Hematocrit (HCT) in the MCT21 group; D: Hematocrit (HCT) in the $\mathrm{CH}$ group. Sal, injected with saline; MCT, injected with monocrotaline (MCT); CLZ-, fed rat chow without $\mathrm{CLZ} ; \mathrm{CLZ}+$, fed rat chow with $\mathrm{CLZ}$. (n)= number of rats, means $\pm \mathrm{SE}$ the Sal28/CLZ- and MCT28/CLZ- groups, sRVP and $\mathrm{RV} / \mathrm{LV}+\mathrm{S}$ were significantly higher in the MCT28/CLZgroup: sRVP, $30.20 \pm 3.35(\mathrm{n}=3)$ versus $76.63 \pm 3.20$ $(\mathrm{n}=8) \mathrm{mmHg}(P<0.05)$ (Fig. $5 \mathrm{C}) ; \mathrm{RV} / \mathrm{LV}+\mathrm{S}, 0.28 \pm 0.02$ $(\mathrm{n}=5)$ versus $0.63 \pm 0.04(\mathrm{n}=8)(P<0.05)$ (Fig. $5 \mathrm{H})$. In the comparison of the effects of CLZ treatment between the MCT28/CLZ+ and MCT28/CLZ- groups, sRVP $[35.28 \pm 1.90(\mathrm{n}=8) \mathrm{mmHg}(P<0.05)($ Fig. $5 \mathrm{C})]$ and RV/ $\mathrm{LV}+\mathrm{S}[0.32 \pm 0.04(\mathrm{n}=9)(P<0.05)]$ in the MCT28/ CLZ+ group were significantly lower than the values of the MCT28/CLZ- group (Fig. 5H), suggesting again that CLZ treatment ameliorated the development of $\mathrm{PH}$ and RVH. CLZ treatment significantly prolonged survival for an additional 4 days beginning at 26 days after the MCT injection in rats with MCT-induced PH (Fig. 8).

\section{$\mathrm{CH}$ model}

$\mathrm{CH}$ caused $\mathrm{PH}$ with an mPAP of $29.1 \pm 1.5 \mathrm{mmHg}$ $(\mathrm{n}=10)(\mathrm{CH} / \mathrm{CLZ}-)$ compared to $17.5 \pm 0.5 \mathrm{mmHg}$ in the Air/CLZ- group $(\mathrm{n}=10)(P<0.05)$. No significant differences were observed between rats in the $\mathrm{CH} / \mathrm{CLZ}+$ and $\mathrm{CH} / \mathrm{CLZ}$ - groups (Fig. 5B). The RV/LV+S was higher in

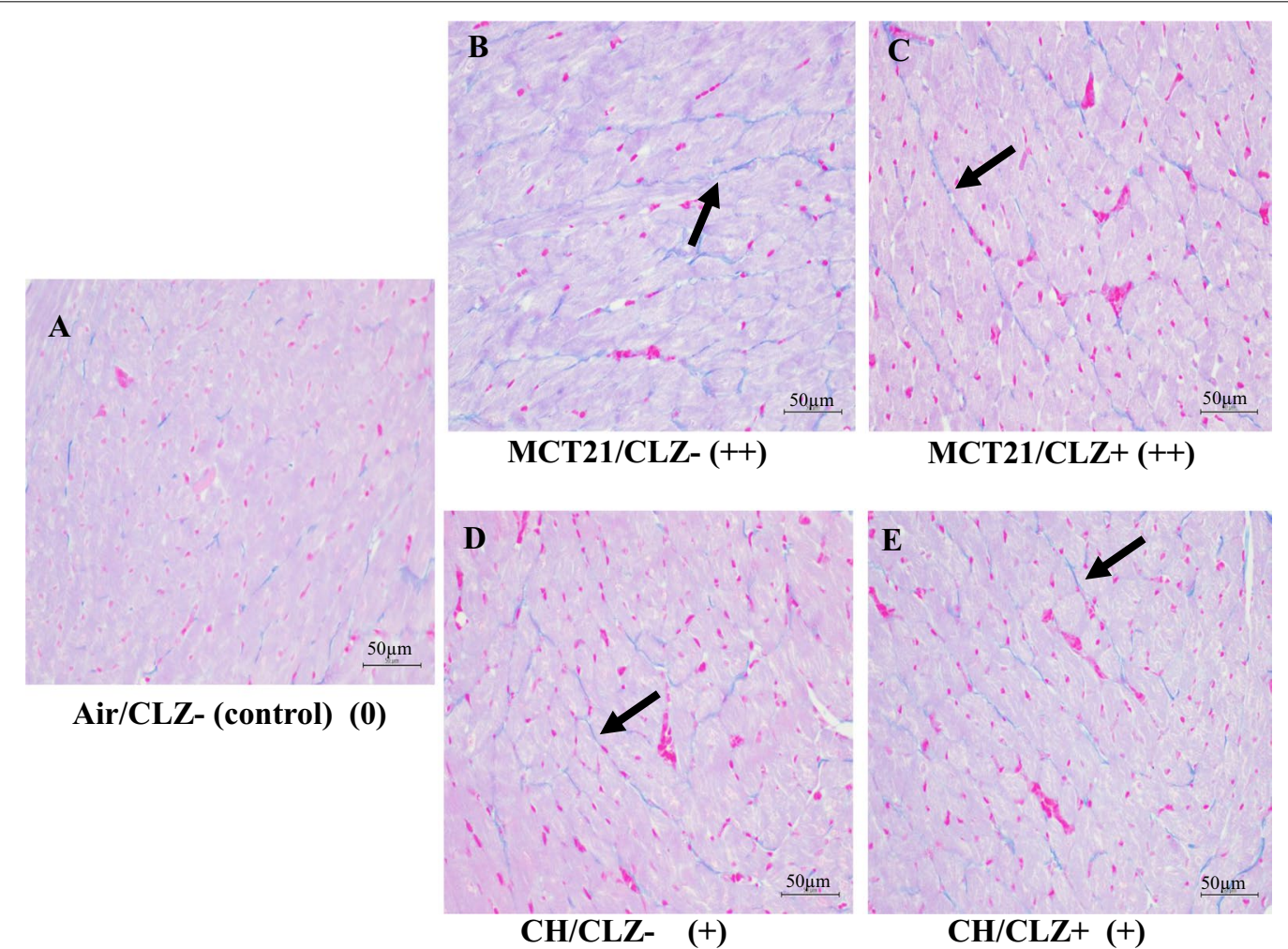

Fig. 7 Collagen staining in the right ventricle. Representative photomicrographs of collagen staining in the right ventricle detected using Masson's trichrome staining. Images were captured with a microscope at $\times 400$ magnification, and the scale bars in lower right corner represent $50 \mu \mathrm{m}$. A: Air/CLZ- (control), rats exposed to ambient air and fed rat chow without CLZ; B: MCT21/CLZ-, rats injected with MCT and fed rat Chow with CLZ; C: MCT21/CLZ +, rats injected with MCT and fed rat chow without CLZ; $\mathbf{D}: C H / C L Z-$, rats exposed to chronic hypoxia and fed rat chow without CLZ; E: $\mathrm{CH} / \mathrm{CLZ}+$, rats exposed to chronic hypoxia and fed rat chow with $\mathrm{CLZ}$. Fibrosis scale: $0=$ normal, $(+)=$ mild, and $(++)=$ moderate. The blue color indicates collagen (allows) 


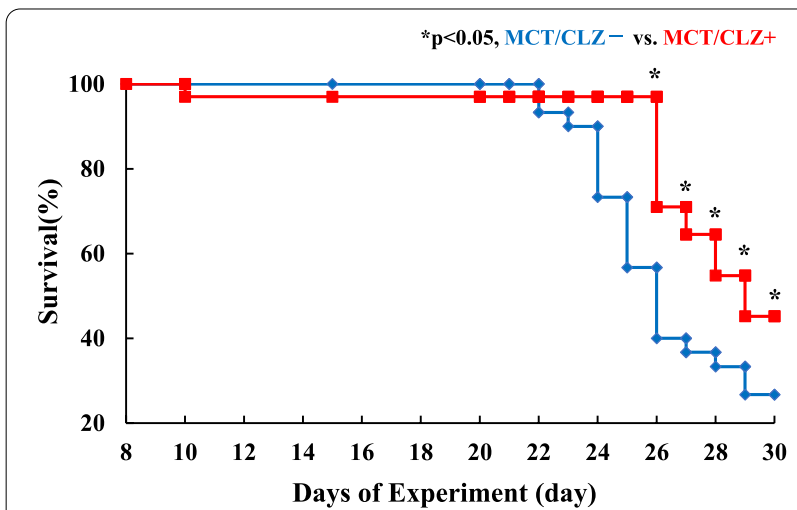

Fig. 8 Kaplan-Meier survival curve of rats treated with and without $\mathrm{CLZ}$ after the MCT injection. Thirty rats treated with $\mathrm{CLZ}(\mathrm{MCT} / \mathrm{CLZ}+)$ (red line) and 30 rats treated without CLZ (MCT/CLZ-) (blue line) were used. MCT/CLZ-, rats injected with MCT and fed rat chow without $\mathrm{CLZ} ; \mathrm{MCT} / \mathrm{CLZ}+$, rats injected with MCT and fed rat chow with CLZ. $P<0.05$ compared to rats treated without $C L Z$ the $\mathrm{CH} / \mathrm{CLZ}$ - group at $0.41 \pm 0.03(\mathrm{n}=13)$ than in the Air/CLZ- group at $0.27 \pm 0.06(\mathrm{n}=10)(P<0.05)$. Significant differences in $\mathrm{RV} / \mathrm{LV}+\mathrm{S}$ were not observed between the $\mathrm{CH} / \mathrm{CLZ}+$ and $\mathrm{CH} / \mathrm{CLZ}$ - groups (Fig. 5G). The $\mathrm{mPAP} / \mathrm{mAP}$ ratio was also higher in the $\mathrm{CH} / \mathrm{CLZ}$ - group than in the Air/CLZ- group, with no significant difference between the $\mathrm{CH} / \mathrm{CLZ}+$ and $\mathrm{CH} / \mathrm{CLZ}$ - groups (Fig. 5E). No significant differences in $\mathrm{mAP}$ were observed among the 4 groups (Fig. 6B). (mAP: Air/CLZ- 105.0 \pm 2.15 $(\mathrm{n}=8), \quad$ Air/CLZ $+101.88 \pm 2.06 \quad(\mathrm{n}=8), \quad \mathrm{CH} / \mathrm{CLZ}-$ $104.0 \pm 2.39(\mathrm{n}=13), \mathrm{CH} / \mathrm{CLZ}+103.78 \pm 3.66 \quad(\mathrm{n}=14)$ $\mathrm{mmHg}$ ). The staining of collagen fibers in the right ventricle was obtained in control rat (Fig. 7A). Staining for collagen fibers in the right ventricle was increased in $\mathrm{CH}$ rat, but the CLZ treatment did not seem to decrease this increased staining (Fig. 7D, E).

\section{Vascular structural changes MCT21 model}

The \%Muscularization was higher in arteries with external diameters between 15 and $50 \mu \mathrm{m}$ (Fig. 9A) and

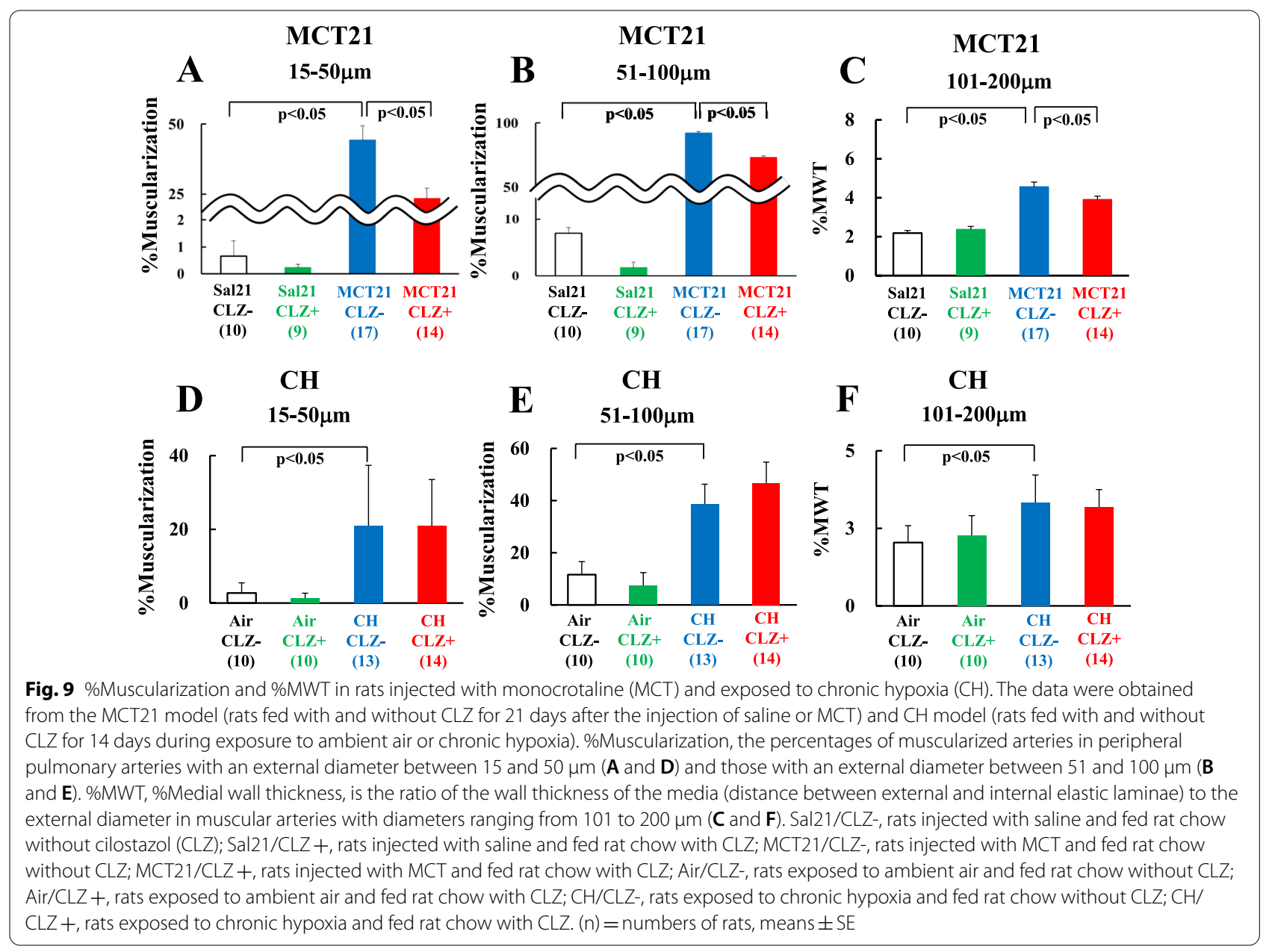


arteries with diameters between 51 and $100 \mu \mathrm{m}$ (Fig. 9B)

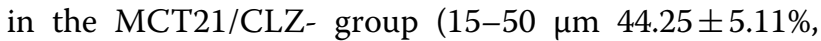
$51-100 \mu \mathrm{m} 92.24 \pm 2.98 \%)(\mathrm{n}=17)$ than in the Sal21/ CLZ- group $\quad(15-50 \mu \mathrm{m} \quad 0.66 \pm 0.55 \% \quad(P<0.05)$, $51-100 \mu \mathrm{m} 7.50 \pm 3.43 \%(P<0.05))(\mathrm{n}=10)$. The MCT21/ CLZ+ group $\quad(15-50 \mu \mathrm{m} \quad 23.36 \pm 3.73 \% \quad(P<0.05)$, $51-100 \mu \mathrm{m} 73.46 \pm 5.80 \%(P<0.05))(\mathrm{n}=14)$ exhibited a significantly lower \%Muscularization in both sizes of arteries than the MCT21/CLZ- group (Fig. 9A, B). The \%MWT in the MCT21/CLZ- group $(4.56 \pm 0.24 \%$ $(\mathrm{n}=17))$ was higher than that in the Sal21/CLZ- group $(2.18 \pm 0.13 \%(\mathrm{n}=10))(P<0.05)$ in the muscular arteries with external diameters ranging from 101 and $200 \mu \mathrm{m}$ and usually accompanied by terminal or respiratory bronchioles (Fig. 9C). The MCT21/CLZ + group (3.91 $\pm 0.17 \%$ $(\mathrm{n}=14)(P<0.05))$ had a significantly lower \%MWT than the MCT21/CLZ- group (Fig. 9C).

\section{CH model}

The \%Muscularization (Fig. 9D, E) and \%MWT (Fig. 9F) were significantly higher in the $\mathrm{CH} / \mathrm{CLZ}$ - group (\%Muscularization: $15-50 \mu \mathrm{m} \quad 20.97 \pm 4.37 \%, \quad 51-100 \mu \mathrm{m}$ $38.51 \pm 7.79 \%$; \%MWT: $101-200 \mu \mathrm{m} \quad 3.32 \pm 0.26 \%)$ $(\mathrm{n}=13)$ than in the Air/CLZ- group (\%Muscularization: $15-50 \mu \mathrm{m} 2.74 \pm 0.91 \% \quad(P<0.05), \quad 51-100 \mu \mathrm{m}$ $11.59 \pm 5.03 \% \quad(P<0.05)$; $\%$ MWT: $101-200 \quad \mu \mathrm{m}$ $2.04 \pm 0.18 \% \quad(P<0.05)) \quad(\mathrm{n}=10)$, whereas the $\mathrm{CH} /$ CLZ+(\%Muscularization: $15-50 \mu \mathrm{m} \quad 20.89 \pm 3.50 \%$, 51-100 $\mu \mathrm{m} \quad 46.71 \pm 8.02 \%$; \%MWT: $101-200 \mu \mathrm{m}$ $3.19 \pm 0.16 \%)(\mathrm{n}=14)$ was not significantly different from the $\mathrm{CH} / \mathrm{CLZ}$ - group (Fig. 9D-F).

\section{Hematocrit}

Hematocrit was similar among the Sal21/CLZ-, Sal21/ CLZ+, MCT21/CLZ- and MCT21/CLZ+groups: $43.9 \pm 0.7 \% \quad(n=9), \quad 41.4 \pm 1.4 \% \quad(n=9), \quad 41.3 \pm 1.5 \%$ $(\mathrm{n}=16)$, and $42.4 \pm 1.5 \%(\mathrm{n}=14)$, respectively. Hematocrit in the $\mathrm{CH} / \mathrm{CLZ}$ - group $(56.1 \pm 1.6 \%, \mathrm{n}=14)$ was significantly higher than in the Air/CLZ- group (42.8 $\pm 1.7 \%$, $\mathrm{n}=9)$. The $\mathrm{CH} / \mathrm{CLZ}+$ group $(56.1 \pm 1.6 \%, \mathrm{n}=15)$ had values similar to those of the $\mathrm{CH} / \mathrm{CLZ}$ - group (Fig. $6 \mathrm{C}$, D).

\section{Western blotting and PCR eNOS and peNOS}

MCT had no effect on eNOS protein expression (Fig. 10A, B), whereas $\mathrm{CH}$ upregulated eNOS protein expression (Fig. 10C). MCT also had no effect on eNOS mRNA levels (Fig. 10G, H), whereas $\mathrm{CH}$ increased eNOS mRNA expression (Fig. 10I). MCT decreased the level of the peNOS protein (Fig. 10D, E), whereas $\mathrm{CH}$ did not (Fig. 10F). CLZ increased eNOS mRNA levels in the
MCT21 group (Fig. 10G) and decreased peNOS levels in the $\mathrm{CH}$ group (Fig. 10F).

\section{$A K T$ and $p A K T$}

MCT significantly downregulated the level of the AKT protein in the MCT21 model (Fig. 11A) and insignificantly downregulated in MCT28 model (Fig. 11B). MCT also downregulated the pAKT protein insignificantly in MCT21 model (Fig. 11D) and significantly in the MCT28 model (Fig. 11E). CLZ significantly attenuated this decrease in pAKT protein levels in the MCT28 model (Fig. 11E). Although CLZ did not increase the AKT mRNA levels in MCT21 model (Fig. 11G), CLZ slightly but significantly increased AKT mRNA expression in the MCT28 model (Fig. $11 \mathrm{H}$ ). In the $\mathrm{CH}$ model, the levels of the AKT mRNA, AKT protein and pAKT protein were unchanged, and CLZ had no effect (Fig. 11C, F, I).

\section{IKB and HMGB-1}

MCT downregulated IkB (Fig. 12A, B) and HMGB-1 (Fig. 12D, E) protein expression in both the MCT21 and MCT28 models (Fig. 12A,B, D, E). CLZ significantly attenuated the downregulation of both $\mathrm{I}_{\kappa} \mathrm{B}$ (Fig. 12B) and HMGB-1 (Fig. 12E) protein expression in the MCT28 model. In the $\mathrm{CH}$ model, the expression of the IKB and HMGB-1 proteins was unchanged, and CLZ had no effect (Fig. 12C, F).

\section{MCP-1}

The MCP-1 mRNA was expressed at higher levels in the MCT21/CLZ- group than in the Sal21/CLZ- group. No significant difference was observed between the MCT21/ CLZ- and MCT21/CLZ+groups (Fig. 13A). In the MCT28 and $\mathrm{CH}$ models, differences in MCP-1 mRNA levels were not observed among the groups (Fig. 13B, C).

\section{Discussion}

The MCT and $\mathrm{CH}$ models were used to determine the difference in the effect of CLZ on the development of PH in these models. CLZ treatment ameliorated the development of $\mathrm{PH}$ and $\mathrm{RVH}$ and the increase in \%Muscularization (percentages of muscularized arteries in peripheral pulmonary arteries) and \%MWT (medial wall thickness of muscular arteries) in the MCT PH model. In contrast, CLZ did not ameliorate these hypertensive changes in the $\mathrm{CH}$ model. In the $\mathrm{MCT}$-exposed lung, the IкB protein level decreased and the MCP-1 mRNA level increased, whereas these changes were not detected in the $\mathrm{CH}$ model.

This study had several limitations. First, the present results were only obtained from adult male rats, and we must be cautious when discussing neonatal and juvenile 

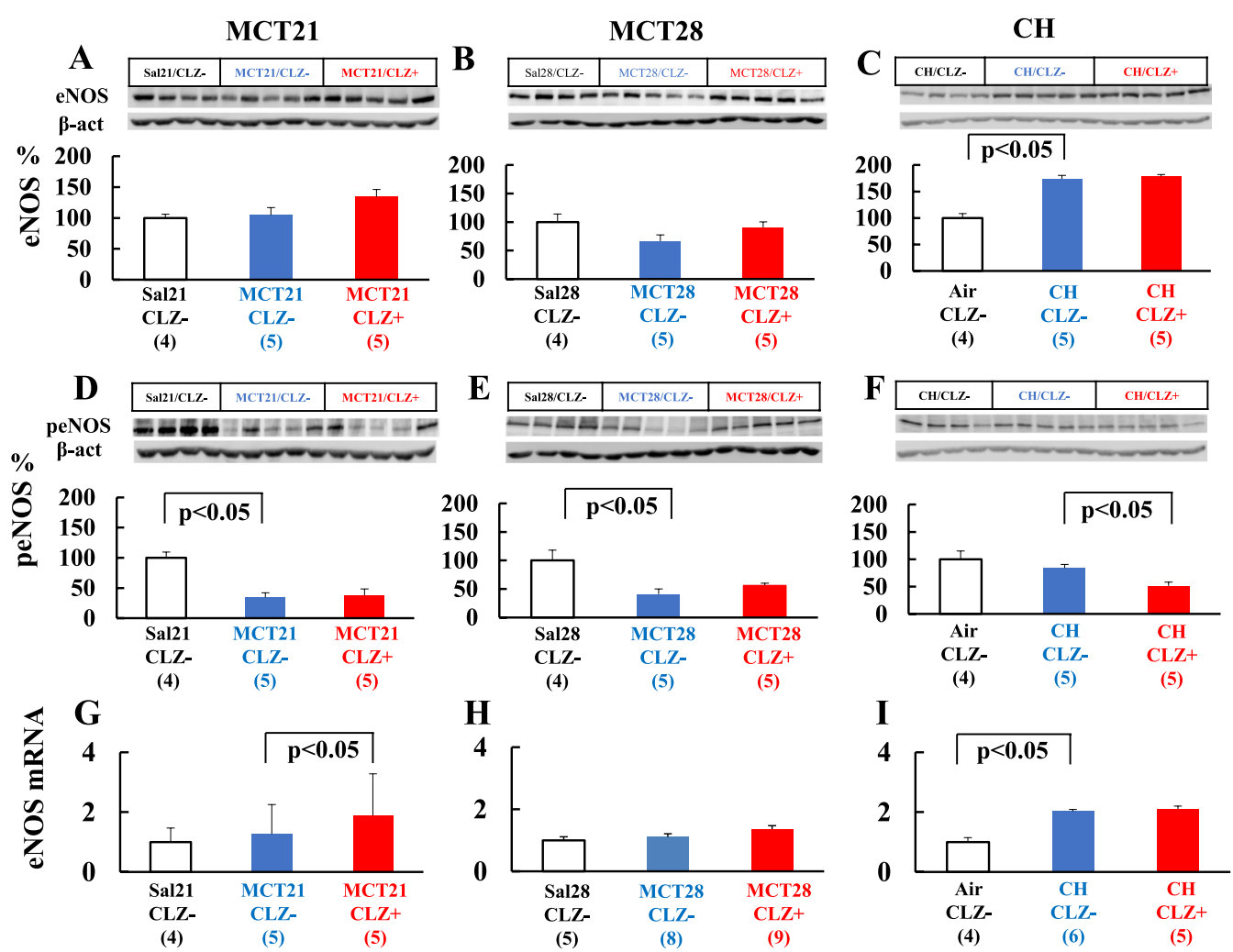

Fig. 10 Levels of the endothelial nitric oxide synthase (eNOS) and phosphorylated eNOS proteins and eNOS mRNA. The left column (MCT21) represents rats in the MCT21 group.; The middle column (MCT28) represents rats in the MCT28 group.; The right column (CH) represents rats in the CH group. A: eNOS protein in the MCT21 group; $\mathbf{B}$ : eNOS protein in the MCT28 group; $\mathbf{C}$ : eNOS proein in the CH group; D: peNOS protein in the MCT21 group; $\mathbf{E}$ : peMOS protein in the MCT28 group; $\mathbf{F}$ : peNOS proein in the $\mathrm{CH}$ group; $\mathbf{G}$ : eNOS mRNA in the MCT21 group; $\mathbf{H}$ : eNOS mRNA in the MCT28 group; $\mathbf{I}$ : eNOS mRNA in the CH group. Representative Western blot images showing levels of the eNOS and peNOS proteins (A-F) are presented. Sal, injected with saline; MCT, injected with monocrotaline (MCT). Air, exposed to ambient air; CH, rats exposed to chronic hypoxia; CLZ-, fed rat chow without CLZ; CLZ+, fed rat chow with CLZ. The average intensity of the Sal/CLZ- group in the MCT21 and MCT28 models and Air/ CLZ- group in the CH model was set to $100 \%$. The intensity of each sample was calculated as a percentage of the average value (relative intensity). $(n)=$ number of rats, means $\pm S E$

rats and/or infant and pediatric human patients, since age and sex influence $\mathrm{PH}$ caused by $\mathrm{CH}$ [53], and animal models do not completely recapitulate the human disease [16]. In most studies using animal models of $\mathrm{PH}$, investigators have only used male rats $[8,10,11,13,15,43,48$, $53,54]$. Since we also only used male rats to establish rat models of experimental PH $[6,12,31,45]$, we used only male rats in the present study according to our own and other researchers' studies. Second, a higher dosage of CLZ was administered in the present study than in the previous study [43]. We used this concentration because chow containing $0.3 \%$ CLZ was administered to spontaneously hypertensive rats [52]. The rats in the previous study [43] did not have lethal conditions compared with the rats in the present study. Third, the protocol was preventive rather than therapeutic after the occurrence of PH. However, an interventional treatment approach would represent a better translational approach, e.g., treatment starting on day 21 in the MCT model. Fourth, this study is observational and not mechanistic. Because (1) CLZ increases AKT phosphorylation in cell-based studies [38, 40], (2) PI3/AKT-dependent NO production has been reported $[38,55]$, and (3) NO production and/or administration ameliorates the development of hypertensive pulmonary vascular changes $[6,7,33]$, we determined the levels of the AKT, pAKT, eNOS mRNA, eNOS, and peNOS proteins. Since an attenuation of the decrease in the levels of pAKT, an active form of AKT, was detected in the MCT model with no changes in the $\mathrm{CH}$ model, this effect of CLZ might partially explain the difference in the effect of CLZ on the two models. Although one of the targets of pAKT is eNOS [55], we did not detect an increase in peNOS levels in the whole lung. Immunohistochemistry of lung tissue might help identify cells with increased peNOS expression and 


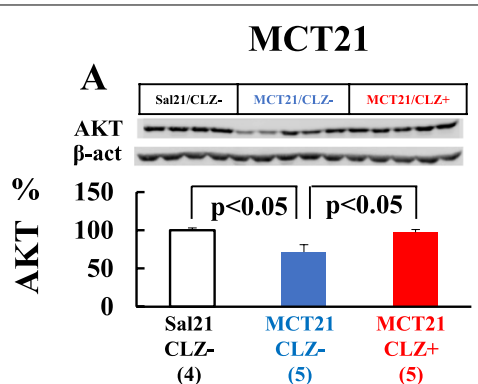

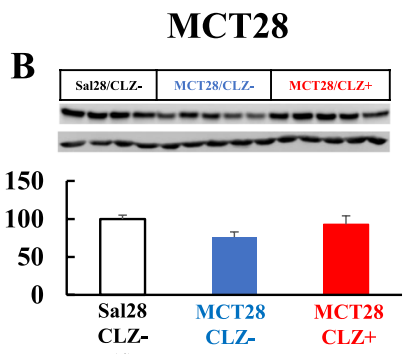

(4) (5) (5)

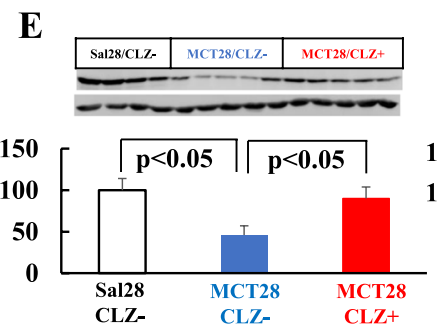

(4)

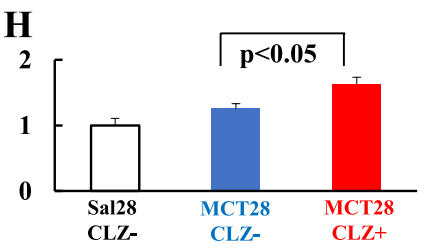

(5)

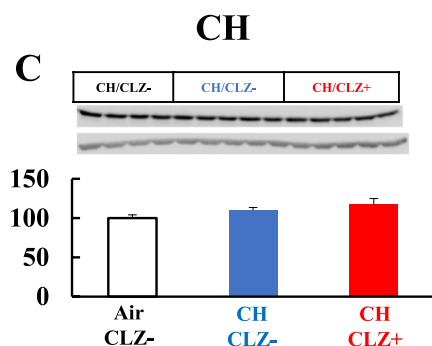

(4)

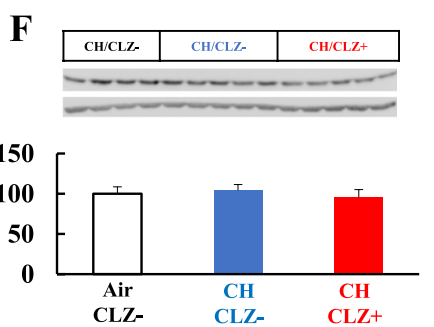

$\begin{array}{lll}\text { (4) } & \text { CLZ } & \text { CLZ } \\ & (5) & \text { (5) }\end{array}$

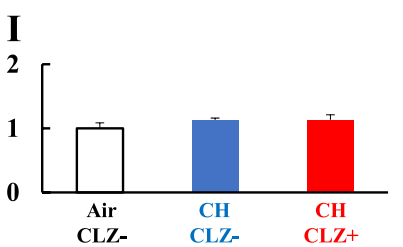

(4) $\quad$ (6)

Fig. 11 Levels of the AKT and phosphorylated AKT (pAKT) proteins and AKT mRNA. A: AKT protein in the MCT21 group; B: AKT protein in the MCT28 group; $\mathbf{C}$ : AKT protein in the CH group; D: PAKT protein in the MCT21 group; $\mathbf{E}$ : pAKT protein in the MCT28 group; $\mathbf{F}$ : pAKT proein in the CH group; G: AKT mRNA in the MCT21 group; H: AKT mRNA in the MCT28 group; I: AKT mRNA in the CH group. Representative Western blot images show AKT and pAKT protein levels (A-F). Sal, injected with saline; $M C T$, injected with monocrotaline (MCT). Air, exposed to ambient air; $C H$, rats exposed to chronic hypoxia; CLZ-, fed rat chow without CLZ; CLZ+, fed rat chow with CLZ. (n)= number of rats, means \pm SE. See Fig. 9 for the definitions of abbreviations

further determine the relationship between pAKT and peNOS.

Although we did not measure cardiac output in the present study, another study showed no significant difference in cardiac output between saline control rats and MCT rats 2 and/or 3 weeks after the MCT injection $[8,13,48]$. Because systemic arterial pressure was similar among the four groups in the present study, we postulated that cardiac output had been maintained in our MCT21 group. However, as MCT rats ultimately develop right heart failure and potentially develop substantial myocardial inflammation, an assessment of right ventricular function (e.g., cardiac output) and right ventricular changes, such as apoptotic index, right ventricular fibrosis or changes in capillary density, might be helpful. Accordingly, we tried to evaluate fibrosis in the right ventricle by performing Masson's trichrome staining for collagen in a pooled sample of the heart tissues that were originally used to determine $\mathrm{RVH}$, and found that collagen fiber staining in the right ventricle was increased in both MCT and $\mathrm{CH}$ rats, but
CLZ treatment did not seem to decrease these changes. Thus, we did not detect an effect of CLZ on fibrosis in hypertrophic right ventricles. Although technical issues might exist, we did not detect a decrease in right ventricle fibrosis based on collagen staining in CLZ-treated MCT rats, which might simply suggest that CLZ does not correct fibrosis. Combined with the result of another study using ultraviolet-irradiated mice showing that CLZ increased collagen staining in skin [56], CLZ did not decrease the collagen density.

A high hematocrit contributes to a high PAP in the $\mathrm{CH}$ model in addition to hypertensive pulmonary vascular remodeling [11], where the decrease in hematocrit is expected to reduce PAP. Since the hematocrit in both the $\mathrm{CH}$ and MCT models was not changed by CLZ, the attenuation of the MPAP by CLZ treatment was not due to the decrease in hematocrit. Medial hypertrophy of the muscular artery indicates the hypertrophy and hyperplasia of vascular smooth muscle cells, whereas new muscularization of normally nonmuscular arteries indicates the differentiation of pericytes to mature smooth 


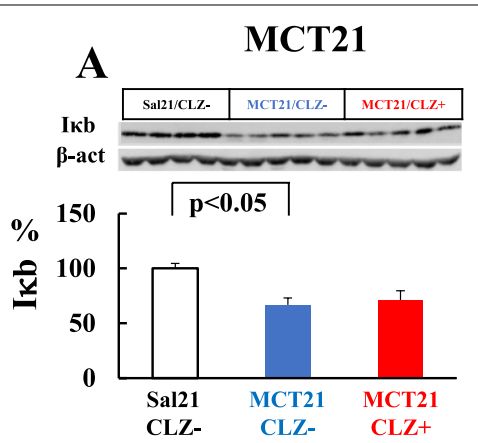

(4) (5)

D

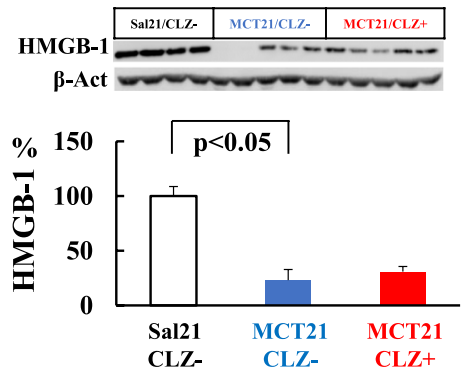

(4) (5)

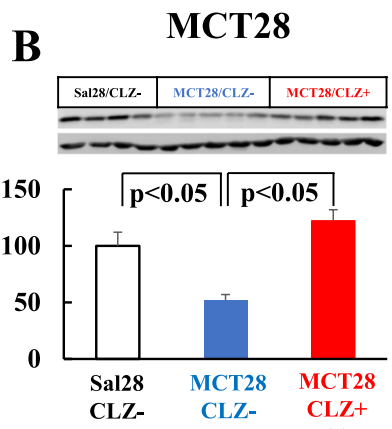

(4)

$\mathbf{E}$

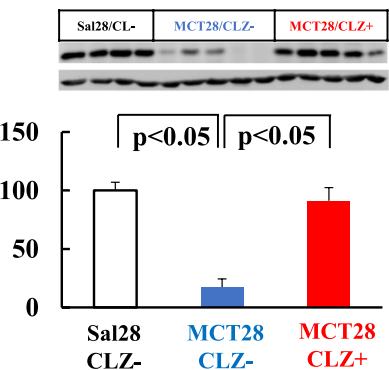

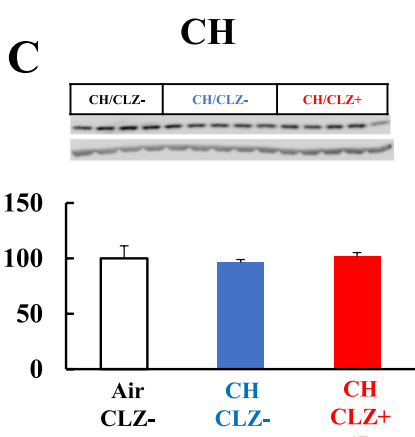

(4)

(5)

(5)

F
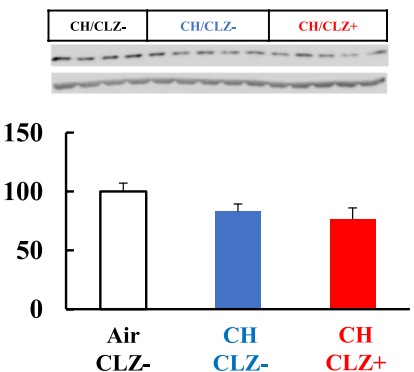

$\begin{array}{lccc}\text { (4) } & \text { CLZ- } & \text { CLZ+ } \\ \text { (5) } & (5)\end{array}$

Fig. 12 Western blot analysis of IKB and HMGB-1 levels. A: IKB protein in the MCT21 group; B: IKB protein in the MCT28 group; C: IKB proein in the CH group; D: HMGB-1 protein in the MCT21 group; E: HMGB-1 protein in the MCT28 group; $\mathbf{F}$ : HMGB-1 proein in the $\mathrm{CH}$ group. Representative Western blot images showing IKB and HMGB-1 levels (A-F). Sal, injected with saline; MCT, injected with monocrotaline (MCT). Air, exposed to ambient air; $\mathrm{CH}$, rats exposed to chronic hypoxia; CLZ-, fed rat chow without CLZ; CLZ+, fed rat chow with CLZ. HMGB-1, High-mobility group box-1. $(n)=$ number of rats, means \pm SE. See Fig. 9 for the definitions of abbreviations

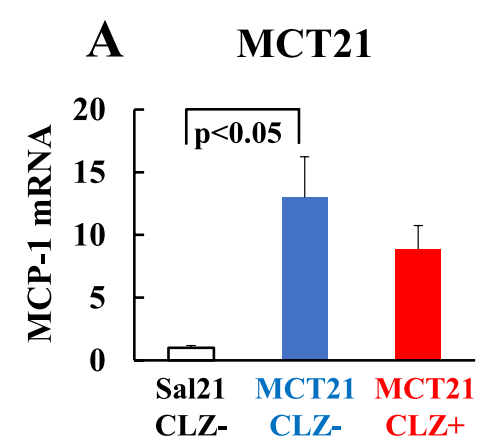

(4)

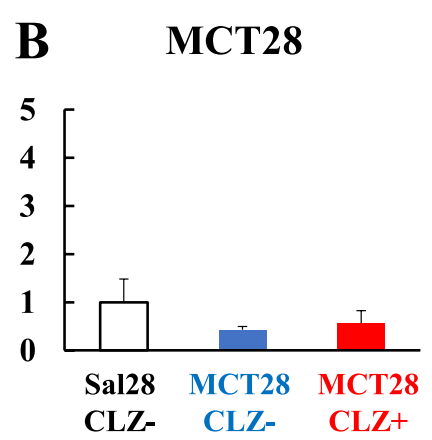

(5)

(8)

(9)

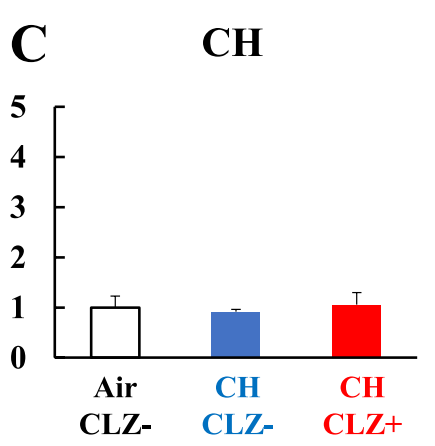

Fig. 13 Expression of the MCP-1 mRNA. A: MCP-1 mRNA in the MCT21 group; $\mathbf{B}$ : MCP-1 mRNA in the MCT28 group; C: MCP-1 mRNA in the CH group. Sal, injected with saline; MCT, injected with monocrotaline (MCT). Air, exposed to ambient air; $C H$, rats exposed to chronic hypoxia; CLZ-, fed rat chow without $\mathrm{CLZ} ; \mathrm{CLZ}+$, fed rat chow with CLZ. MCP-1, Monocyte chemotactic protein-1. (n)= number of rats, means \pm SE. See Fig. 9 for the definitions of abbreviations

muscle cells $[11,12]$. Because CLZ induces NO production through NOS activation $[37,38]$ and an increase in endogenous NO levels might ameliorate the development of hypertensive pulmonary vascular changes $[6,33]$, we determined eNOS and peNOS levels in lungs from both models.
According to previous studies, the expression of the eNOS mRNA is increased in the lungs of $\mathrm{CH}$-induced $\mathrm{PH}$ rats [51, 57], consistent with the present results. Since CLZ increases NOS expression in cultured endothelium $[37,38]$, we expected to observe the upregulation of NOS in lung tissue from the $\mathrm{CH}$ group exposed to CLZ. CLZ 
might have no effect on NOS synthesis, at least in whole lung tissue from $\mathrm{CH}$-exposed rats, since eNOS protein levels in the lung tissue were similar between $\mathrm{CH}$ induced $\mathrm{PH}$ rats treated with and without CLZ. Based on this result, the combined $\mathrm{CH}$ and CLZ treatment did not further increase eNOS expression compared with $\mathrm{CH}$-induced NOS upregulation. Although eNOS mRNA expression was increased by CLZ in the MCT21 model, which is consistent with an earlier study [43], CLZ had no effect on the levels of the eNOS and peNOS proteins in either model. We are unable to easily explain the preventive effect of CLZ on the MCT model through increased $\mathrm{NO}$ production.

MCT-induced PH rats $[6,8,12-15,17,18,33,43,45-$ 50] have been used to investigate pulmonary vascular remodeling in inflammatory-related $\mathrm{PH}$, including ARDS $[4,5]$. $\mathrm{CH}$-induced $\mathrm{PH}[6,7,9-11,31,32,51]$ is a type of $\mathrm{PH}$ caused by hypoxia and has been observed in patients residing at high altitude and patients with chronic obstructive pulmonary disease. Endothelial injury precedes the increase in PAP in MCT-induced PH [48], whereas the increase in PAP precedes the development of vascular changes in $\mathrm{CH}$-induced $\mathrm{PH}$ [10]. A previous study showed that chronic NO inhalation prevented the development of $\mathrm{PH}$ and pulmonary vascular remodeling in $\mathrm{CH}$-induced $\mathrm{PH}$ [7] but not in MCT-induced $\mathrm{PH}$ [12]. NO inhalation causes selective pulmonary vasodilation. Thus, the different effects of inhaled NO on different $\mathrm{PH}$ models suggest that reversing vasoconstriction is effective at preventing the development of some forms of $\mathrm{PH}$ in which vasoconstriction is the initial insult. Since CLZ did not prevent the development of $\mathrm{CH}$-induced $\mathrm{PH}$, we speculate that CLZ has a less potent pulmonary vasodilating effect. Endothelial injury is the initial insult in MCT-induced PH [48]. CLZ has been reported to promote endothelial regeneration in injured carotid arteries [58] and endothelial proliferation in lymphatics [54].

Because (1) the expression of ІкB is decreased in lungs from MCT-induced PH rats [45]; (2) the increase in IкB levels induced by pyrrolidine dithiocarbamate (PDTC), an $\mathrm{NF}_{\kappa} \mathrm{B}$ inhibitor, ameliorated the development of hypertensive pulmonary vascular changes [45]; and (3) CLZ reduces NFKB activity $[59,60]$, we determined the expression of $I \kappa B$ in lung tissue and the effect of CLZ. $\mathrm{NFKB}$ is a transcription factor that regulates the transcription of genes involved in inflammatory responses. A decrease in levels of the $I \kappa B \alpha$ protein has been reported to be associated with increased NFKB activity [61]. I $\mathrm{KB} \alpha$ expression was unchanged in $\mathrm{CH}$-induced $\mathrm{PH}$ rats but decreased in MCT-induced PH rats in the current study, consistent with our previous study [45] suggesting that inflammatory components play a greater role in the etiology of MCT than in the $\mathrm{CH}$ model. Although we were unable to identify the IкB-expressing cells using Western blot analysis because we used whole lung tissue, endothelial cells and mononuclear cells might express this protein because a previous study in our lab showed an increased number of endothelial cells and infiltrated mononuclear cells that express the phosphorylated p65 subunit of $N F \kappa B$ in the nucleus [45]. The increased lung expression of the MCP-1 mRNA in the present study also supports the inflammatory component of the MCT model. The mechanism and role of MCP-1 in the inflammatory response are chemotactic and activating effects on monocytes/macrophages [50]. In the MCT model, we and others have documented macrophage infiltration into the alveolar wall by 14 days after MCT injection [15, 45]. The plasma and bronchoalveolar lavage fluid (BALF) MCP-1 levels increase transiently and then return to normal levels [50]. We also showed that lung expression of the MCP-1 mRNA was elevated in MCT21 rats in the present study and showed increases in BALF MCP-1 and TNF $\alpha$ levels measured using ELISAs in a previous study [14], suggesting the presence of inflammation in MCT rats. The anti-inflammatory effect of CLZ [40, 62] might explain the reversal of decreased levels of IKB $\alpha$ in the lungs of MCT-injected rats. CLZ has been reported to inactivate $\mathrm{NF \kappa B}[59,60]$. Moreover, retinoic acid prevents the development of MCT-induced $\mathrm{PH}$ by inhibiting MMP-1 [47]. NFkB induces the expression of MMP-1 [63], and CLZ was reported to prevent MMP-1 activity in a cell-based study [64].

Because previous studies showed an increased plasma HMGB-1 level in subjects with both MCT- and chronic hypoxia-induced $\mathrm{PH}$ [46], we determined the expression of HMGB-1 in lung tissue and the effect of CLZ. HMGB-1 is normally present as a nuclear protein and is passively released from damaged cells [41]. The lower expression of HMGB-1 in the lung tissue of MCTinjected rats might be due to the increased release of HMGB-1 protein into the circulation, which might reflect damage to the cells. A recent study showed that an increase in serum HMGB-1 is associated with a concurrent decrease in tissue HMGB-1 protein expression [65]. CLZ restored HMGB-1 protein expression to the control level at 28 days after the MCT injection, potentially indicating the ability of CLZ to ameliorate cell damage and prolong survival. Furthermore, CLZ inhibits lipopolysaccharide-activated HMGB-1 release and prolongs the survival of endotoxemic mice [62].

The balance of pulmonary arterial smooth muscle cell proliferation and apoptosis is important to maintain structural and functional integrity. In the MCT model, increased pulmonary arterial smooth muscle cell proliferation and decreased apoptosis are pathogenic mechanisms. Decreased apoptosis might lead to the 
development of $\mathrm{PH}$, whereas the induction of apoptosis relieves PH [2]. Since CLZ exerts an anti-apoptotic effect [43], the inhibitory effect of CLZ on the development of $\mathrm{PH}$ might not be due to the induction of apoptosis.

A decrease in ІкB levels in the MCT model and no changes in IкB levels in the $\mathrm{CH}$ model revealed the etiological difference between these two models; MCT is an inflammatory stimulus, whereas $\mathrm{CH}$ is less inflammatory. We speculate that the anti-inflammatory effects of CLZ might have partially influenced the different physiological and pathological effects of CLZ on the two PH models investigated in the present study. CLZ might ameliorate inflammatory experimental $\mathrm{PH}$. However, from a clinical perspective, the use of CLZ as a PH treatment might be limited. The effect of CLZ was partial, since the mPAP and $\mathrm{RV} / \mathrm{LV}+\mathrm{S}$ did not return to control levels, because the \%Muscularization and \%MWT were only partly ameliorated. The currently registered drugs for $\mathrm{PH}$, such as prostacyclin and/or its analogs, endothelin-receptor blockers, and PDE5 inhibitors, ameliorate the development of PH in both MCT and $\mathrm{CH}$ models [17-20]. We expected that CLZ would prevent $\mathrm{PH}$ in both models, but it did not.

\section{Conclusions}

The administration of CLZ prevented the development of $\mathrm{PH}$ in a rat model of MCT-induced $\mathrm{PH}$, although $\mathrm{CH}$ induced $\mathrm{PH}$ development was not prevented by CLZ. The inhibitory effect of CLZ on the development of PH might depend on the etiology of $\mathrm{PH}$, and alterations in lung AKT, pAKT, and IкB levels might partially be related to its effects.

\footnotetext{
Abbreviations

PH: Pulmonary hypertension; CLZ: Cilostazol; MCT: Monocrotaline; $\mathrm{CH}$ : Chronic (hypobaric) hypoxia; RV/LV + S: The right ventricle/ weight-to-left ventricle + septum weight ratio; MPAP: Mean pulmonary artery pressure; mAP: Mean artery pressure; sRVP: Systolic right ventricular pressure; PCR: Polymerase chain reaction; \%Muscularization: Percentages of muscularized arteries; \%MWT: Percent medial wall thickness; eNOS: Endothelial nitric oxide synthase; AKT: Serine-threonine protein kinase; MCP-1: Monocyte chemotactic protein-1.
}

\section{Acknowledgements}

We would like to thank Otsuka Pharmaceutical Co. for the gift of the rat chow.

\section{Authors' contributions}

$\mathrm{TI}$ and EZ contributed equally to this work, collected and analyzed the data, and drafted the manuscript. AO, JK, JM, MK, and AO made substantial contributions to data acquisition and reviewing the manuscript. HS, AY, and YM contributed to the study design, statistical analysis, interpretation of data, and final approval of the manuscript. KM conceived the study, participated in its design and coordination, and helped to draft the manuscript. All authors read and approved the final manuscript.

\section{Funding}

This work was financially supported by grants in aid for scientific research from the Japanese Ministry of Education, Science and Culture (Grants-in-Aid 17K1 1075). The funding body played no role in the design of the study and collection, analysis, and interpretation of data and in writing the manuscript.

\section{Availability of data and materials}

All data generated or analyzed during this study are included in this published article [and its supplementary information files].

\section{Declarations}

\section{Ethics approval and consent to participate}

The Animal Care and Use Committee of Mie University School of Medicine approved the research protocol (Nos. 20-34 and 20-35).

\section{Consent for publication}

Not applicable.

\section{Competing interests}

The authors have no competing interests to declare.

\section{Author details}

${ }^{1}$ Department of Anesthesiology and Critical Care Medicine, Mie University Graduate School of Medicine, 2-174 Edobashi, Tsu, Mie 514-8507, Japan.

${ }^{2}$ Fuzhou Children's Hospital of Fujian Province Affiliated with Fujian Medical University, 145-817-Middle Road, Gulou, Fuzhou 350005, Fujian, China. ${ }^{3}$ Faculty of Health Science, Suzuka University of Medical Science, Suzuka, Mie 510-0293, Japan. ${ }^{4}$ Department of Pediatrics, Mie University Graduate School of Medicine, 2-174 Edobashi, Tsu, Mie 514-8507, Japan.

Received: 30 January 2021 Accepted: 25 October 2021

Published online: 20 November 2021

\section{References}

1. Archer SL, Weir EK, Wilkins MR. Basic science of pulmonary arterial hypertension for clinicians: new concepts and experimental therapies. Circulation. 2010;121:2045-66.

2. Rabinovitch M. Molecular pathogenesis of pulmonary arterial hypertension. J Clin Investig. 2008;1 18:2372-9.

3. Rabinovitch M, Keane JF, Norwood WI, Castaneda AR, Reid L. Vascular structure in lung tissue obtained at biopsy correlated with pulmonary hemodynamic findings after repair of congenital heart defects. Circulation. 1984;69:655-67.

4. Snow RL, Davies P, Pontoppidan H, Zapol WM, Reid L. Pulmonary vascular remodeling in adult respiratory distress syndrome. Am Rev Respir Dis. 1982;126:887-92.

5. Tomashefski JF Jr, Davies P, Boggis C, Greene R, Zapol WM, Reid LM. The pulmonary vascular lesions of the adult respiratory distress syndrome. Am J Pathol. 1983;112:112-26.

6. Mitani Y, Maruyama K, Sakurai M. Prolonged administration of L-arginine ameliorates chronic pulmonary hypertension and pulmonary vascular remodeling in rats. Circulation. 1997:96:689-97.

7. Kouyoumdjian C, Adnot S, Levame M, Eddahibi S, Bousbaa H, Raffestin B. Continuous inhalation of nitric oxide protects against development of pulmonary hypertension in chronically hypoxic rats. J Clin Investig. 1994;94:578-84.

8. Ye CL, Rabinovitch M. Inhibition of elastolysis by SC-37698 reduces development and progression of monocrotaline pulmonary hypertension. Am J Physiol. 1991;261:H1255-67.

9. Zhang E, Maruyama J, Yokochi A, Mitani Y, Sawada H, Nishikawa M, Ma N, Maruyama K. Sarpogrelate hydrochloride, a serotonin 5HT2A receptor antagonist, ameliorates the development of chronic hypoxic pulmonary hypertension in rats. J Anesth. 2015;29:715-23.

10. Rabinovitch M, Gamble W, Nadas AS, Miettinen OS, Reid L. Rat pulmonary circulation after chronic hypoxia: hemodynamic and structural features. Am J Physiol. 1979;236:H818-27. 
11. Maruyama $K$, Ye CL, Woo M, Venkatacharya $H$, Lines LD, Silver MM, Rabinovitch M. Chronic hypoxic pulmonary hypertension in rats and increased elastolytic activity. Am J Physiol. 1991;261:H1716-26.

12. Maruyama J, Maruyama K, Mitani Y, Kitabatake M, Yamauchi T, Miyasaka K. Continuous low-dose NO inhalation does not prevent monocrotaline-induced pulmonary hypertension in rats. Am J Physiol. 1997;272:H517-24.

13. Ilkiw R, Todorovich-Hunter L, Maruyama K, Shin J, Rabinovitch M. SC-39026, a serine elastase inhibitor, prevents muscularization of peripheral arteries, suggesting a mechanism of monocrotaline-induced pulmonary hypertension in rats. Circ Res. 1989;64:814-25.

14. Yamada Y, Maruyama J, Zhang E, Okada A, Yokochi A, Sawada H, Mitani Y, Hayashi T, Suzuki K, Maruyama K. Effect of thrombomodulin on the development of monocrotaline-induced pulmonary hypertension. J Anesth. 2014;28:26-33.

15. Meyrick B, Gamble W, Reid L. Development of Crotalaria pulmonary hypertension: hemodynamic and structural study. Am J Physiol. 1980;239:H692-702.

16. Stenmark KR, Meyrick B, Galie N, Mooi WJ, McMurtry IF. Animal models of pulmonary arterial hypertension: the hope for etiological discovery and pharmacological cure. Am J Physiol Lung Cell Mol Physiol. 2009;297:L1013-32.

17. Hill NS, Warburton RR, Pietras L, Klinger JR. Nonspecific endothelin-receptor antagonist blunts monocrotaline-induced pulmonary hypertension in rats. J Appl Physiol. 1997;83:1209-15.

18. Schermuly RT, Kreisselmeier KP, Ghofrani HA, Yilmaz H, Butrous G, Ermert L, Ermert M, Weissmann N, Rose F, Guenther A, Walmrath D, Seeger W, Grimminger F. Chronic sildenafil treatment inhibits monocrotalineinduced pulmonary hypertension in rats. Am J Respir Crit Care Med. 2004;169:39-45

19. Eddahibi S, Raffestin B, Clozel M, Levame M, Adnot S. Protection from pulmonary hypertension with an orally active endothelin receptor antagonist in hypoxic rats. Am J Physiol. 1995;268:H828-35.

20. Zhao L, Mason NA, Morrell NW, Kojonazarov B, Sadykov A, Maripov A, Mirrakhimov MM, Aldashev A, Wilkins MR. Sildenafil inhibits hypoxia-induced pulmonary hypertension. Circulation. 2001;104:424-8.

21. Zapol WM, Snider MT. Pulmonary hypertension in severe acute respiratory failure. N Engl J Med. 1977;296:476-80.

22. Maruyama K, Nakai Y, Takeuchi M, Mizumoto T, Chikusa H, Muneyuki M. Verapamil reduced pulmonary hypertension in adult respiratory distress syndrome. J Anesth. 1994;8:480-1.

23. Maruyama K, Takeuchi M, Chikusa H, Muneyuki M. Reduction of intrapulmonary shunt by low-dose inhaled nitric oxide in a patient with latestage respiratory distress associated with paraquat poisoning. Intensive Care Med. 1995;21:778-9.

24. Maruyama K, Maruyama J, Utsunomiya H, Furuhashi K, Kurobuchi M, Katayama Y, Yada I, Muneyuki M. Effect of nicardipine on pulmonary hypertension after repair of congenital heart defects in early postoperative period. J Anesth. 1993;7:95-101.

25. Shimpo H, Mitani Y, Tanaka J, Mizumoto T, Onoda K, Tani K, Yuasa H, Yada I, Maruyama K. Inhaled low-dose nitric oxide for postoperative care in patients with congenital heart defects. Artif Organs. 1997;21:10-3.

26. Breitling S, Ravindran K, Goldenberg NM, Kuebler WM. The pathophysiology of pulmonary hypertension in left heart disease. Am J Physiol Lung Cell Mol Physiol. 2015;309:L924-41.

27. Maruyama K, Kobayasi H, Taguchi O, Chikusa H, Muneyuki M. Higher doses of inhaled nitric oxide might be less effective in improving oxygenation in a patient with interstitial pulmonary fibrosis. Anesth Analg. 1995:81:210-1.

28. Zamanian RT, Haddad F, Doyle RL, Weinacker AB. Management strategies for patients with pulmonary hypertension in the intensive care unit. Crit Care Med. 2007:35:2037-50.

29. Goldenberg NM, Rabinovitch M, Steinberg BE. Inflammatory basis of pulmonary arterial hypertension: implications for perioperative and critical care medicine. Anesthesiology. 2019;131:898-907.

30. Klinger JR, Kadowitz PJ. The nitric oxide pathway in pulmonary vascular disease. Am J Cardiol. 2017;120:S71-9.

31. Maruyama J, Jiang BH, Maruyama K, Takata M, Miyasaka K. Prolonged nitric oxide inhalation during recovery from chronic hypoxia does not decrease nitric oxide-dependent relaxation in pulmonary arteries. Chest. 2004:126:1919-25.
32. Maruyama J, Maruyama K. Impaired nitric oxide-dependent responses and their recovery in hypertensive pulmonary arteries of rats. Am J Physiol. 1994;266:H2476-88.

33. Zhao YD, Courtman DW, Deng Y, Kugathasan L, Zhang Q, Stewart DJ. Rescue of monocrotaline-induced pulmonary arterial hypertension using bone marrow-derived endothelial-like progenitor cells: efficacy of combined cell and eNOS gene therapy in established disease. Circ Res. 2005;96:442-50.

34. Hiatt WR. The US experience with cilostazol in treating intermittent claudication. Atheroscler Suppl. 2005;6:21-31.

35. Tsuchikane E, Fukuhara A, Kobayashi T, Kirino M, Yamasaki K, Kobayashi T, Izumi M, Otsuji S, Tateyama H, Sakurai M, Awata N. Impact of cilostazol on restenosis after percutaneous coronary balloon angioplasty. Circulation. 1999;100:21-6.

36. Noma K, Higashi Y. Cilostazol for treatment of cerebral infarction. Expert Opin Pharmacother. 2018;19:1719-26.

37. Suzuki K, Uchida K, Nakanishi N, Hattori Y. Cilostazol activates AMP-activated protein kinase and restores endothelial function in diabetes. Am J Hypertens. 2008;21:451-7.

38. Hashimoto A, Miyakoda G, Hirose Y, Mori T. Activation of endothelial nitric oxide synthase by cilostazol via a CAMP/protein kinase A- and phosphatidylinositol 3-kinase/Akt-dependent mechanism. Atherosclerosis. 2006;189:350-7.

39. Ikeda U, Ikeda M, Kano S, Kanbe T, Shimada K. Effect of cilostazol, a cAMP phosphodiesterase inhibitor, on nitric oxide production by vascular smooth muscle cells. Eur J Pharmacol. 1996;314:197-202.

40. Hassan M, Ibrahim MA, Hafez HM, Mohamed MZ, Zenhom NM, Abd Elghany HM. Role of Nrf2/HO-1 and PI3K/Akt genes in the hepatoprotective effect of cilostazol. Curr Clin Pharmacol. 2019;14:61-7.

41. Andersson U, Tracey KJ. HMGB1 is a therapeutic target for sterile inflammation and infection. Annu Rev Immunol. 2011:29:139-62.

42. Sakamoto T, Ohashi W, Tomita K, Hattori K, Matsuda N, Hattori Y. Antiinflammatory properties of cilostazol: its interruption of DNA binding activity of NF-kB from the Toll-like receptor signaling pathways. Int Immunopharmacol. 2018:62:120-31.

43. Chang LT, Sun CK, Sheu JJ, Chiang CH, Youssef AA, Lee FY, Wu CJ, Yip HK. Cilostazol therapy attenuates monocrotaline-induced pulmonary arterial hypertension in rat model. Circ J. 2008;72:825-31.

44. Simonneau G, Gatzoulis MA, Adatia I, Celermajer D, Denton C, Ghofrani A, Gomez Sanchez MA, Krishna Kumar R, Landzberg M, Machado RF, Olschewski H, Robbins IM, Souza R. Updated clinical classification of pulmonary hypertension. J Am Coll Cardiol. 2013;62:D34-41.

45. Sawada H, Mitani Y, Maruyama J, Jiang BH, Ikeyama Y, Dida FA, Yamamoto H, Imanaka-Yoshida K, Shimpo H, Mizoguchi A, Maruyama K, Komada Y. A nuclear factor-kappaB inhibitor pyrrolidine dithiocarbamate ameliorates pulmonary hypertension in rats. Chest. 2007;132:1265-74.

46. Dai M, Xiao R, Cai L, Ge T, Zhu L, Hu Q. HMGB1 is mechanistically essential in the development of experimental pulmonary hypertension. Am J Physiol Cell Physiol. 2019;316:C175-85.

47. Qin Y, Zhou A, Ben X, et al. All-trans retinoic acid in pulmonary vascular structural remodeling in rats with pulmonary hypertension induced by monocrotaline. Chin Med J. 2001;114:462-5.

48. Rosenberg HC, Rabinovitch M. Endothelial injury and vascular reactivity in monocrotaline pulmonary hypertension. Am J Physiol. 1988;255:H1484-91.

49. Voelkel NF, Tuder RM, Bridges J, Arend WP. Interleukin-1 receptor antagonist treatment reduces pulmonary hypertension generated in rats by monocrotaline. Am J Respir Cell Mol Biol. 1994;11:664-75.

50. Kimura H, Kasahara Y, Kurosu K, Sugito K, Takiguchi Y, Terai M, Mikata A, Natsume M, Mukaida N, Matsushima K, Kuriyama T. Alleviation of monocrotaline-induced pulmonary hypertension by antibodies to monocyte chemotactic and activating factor/monocyte chemoattractant protein-1. Lab Investig. 1998;78:571-81.

51. Le Cras TD, Xue C, Renqasamy A, et al. Chronic hypoxia upregulates endothelial and inducible NO synthase gene and protein expression in rat lung. Am J Physiol. 1996;270:L164-170.

52. Otsuka Pharmaceutical Co. LTD. Standard Commondity Classification Number of Japan 873399. PLETAAL OD Tablets 50mg.100mg, Medical attachment, HD89D2B01, 2019 
53. Rabinovitch M, Gamble WJ, Miettinen OS, Reid L. Age and sex influence on pulmonary hypertension of chronic hypoxia and on recovery. Am J Physiol. 1981;240:H62-72.

54. Kimura T, Hamazaki TS, Sugaya M, Fukuda S, Chan T, Tamura-Nakano M, Sato S, Okochi H. Cilostazol improves lymphatic function by inducing proliferation and stabilization of lymphatic endothelial cells. J Dermatol Sci. 2014;74:150-8.

55. Zhang XP, Hintze TH. CAMP signal transduction induces eNOS activation by promoting PKB phosphorylation. Am J Physiol Heart Circ Physiol. 2006;290:H2376-84

56. Kim HN, Gil CH, Kim YR, Shin HK, Choi BT. Anti-photoaging properties of the phosphodiesterase 3 inhibitor cilostazol in ultraviolet B-irradiated hairless mice. Sci Rep. 2016;6:31169.

57. Tyler RC, Muramatsu M, Abman SH, et al. Variable expression of endothelial NO synthase in three forms of rat pulmonary hypertension. Am J Physiol. 1999;276:L297-303.

58. Kawabe-Yako R, li M, Masuo O, Asahara T, Itakura T. Cilostazol activates function of bone marrow-derived endothelial progenitor cell for re-endothelialization in a carotid balloon injury model. PLOS ONE. 2011;6:e24646.

59. Jung WK, Lee DY, Park C, Choi YH, Choi I, Park SG, Seo SK, Lee SW, Yea SS, Ahn SC, Lee CM, Park WS, Ko JH, Choi IW. Cilostazol is anti-inflammatory in BV2 microglial cells by inactivating nuclear factor-kappaB and inhibiting mitogen-activated protein kinases. Br J Pharmacol. 2010;159:1274-85.

60. Park WS, Jung WK, Lee DY, Moon C, Yea SS, Park SG, Seo SK, Park C, Choi YH, Kim GY, Choi JS, Choi IW. Cilostazol protects mice against endotoxin shock and attenuates LPS-induced cytokine expression in RAW 264.7 macrophages via MAPK inhibition and NF-kappaB inactivation: not involved in CAMP mechanisms. Int Immunopharmacol. 2010;10:1077-85.

61. Beg AA, Finco TS, Nantermet PV, Baldwin AS Jr. Tumor necrosis factor and interleukin-1 lead to phosphorylation and loss of I kappa B alpha: a mechanism for NF-kappa B activation. Mol Cell Biol. 1993;13:3301-10.

62. Chang KC. Cilostazol inhibits HMGB1 release in LPS-activated RAW 264.7 cells and increases the survival of septic mice. Thromb Res. 2015;136:456-64.

63. O'Kane CM, Elkington PT, Jones MD, Caviedes L, Tovar M, Gilman RH, Stamp G, Friedland JS. STAT3, p38 MAPK, and NF-kappaB drive unopposed monocyte-dependent fibroblast MMP-1 secretion in tuberculosis. Am J Respir Cell Mol Biol. 2010;43:465-74.

64. Yu BC, Lee DS, Bae SM, Jung WK, Chun JH, Urm SH, Lee DY, Heo SJ, Park SG, Seo SK, Yang JW, Choi JS, Park WS, Choi IW. The effect of cilostazol on the expression of matrix metalloproteinase-1 and type I procollagen in ultraviolet-irradiated human dermal fibroblasts. Life Sci. 2013;92:282-8.

65. Nakamura K, Hatano E, Miyagawa-Hayashino A, Okuno M, Koyama Y, Narita M, Seo S, Taura K, Uemoto S. Soluble thrombomodulin attenuates sinusoidal obstruction syndrome in rat through suppression of high mobility group box 1. Liver Int. 2014;34:1473-87.

\section{Publisher's Note}

Springer Nature remains neutral with regard to jurisdictional claims in published maps and institutional affiliations.
Ready to submit your research? Choose BMC and benefit from:

- fast, convenient online submission

- thorough peer review by experienced researchers in your field

- rapid publication on acceptance

- support for research data, including large and complex data types

- gold Open Access which fosters wider collaboration and increased citations

- maximum visibility for your research: over $100 \mathrm{M}$ website views per year

At BMC, research is always in progress.

Learn more biomedcentral.com/submissions 